\title{
Strain localization in brittle-ductile shear zones: fluid-abundant vs. fluid-limited conditions (an example from Wyangala area, Australia)
}

\section{Spruzeniece and S. Piazolo}

Australian Research Council Centre of Excellence for Core to Crust Fluid Systems/GEMOC, Department of Earth and Planetary Sciences, Macquarie University, NSW, Sydney, Australia

Correspondence to: L. Spruzeniece (liene.spruzeniece@ mq.edu.au)

Received: 10 March 2015 - Published in Solid Earth Discuss.: 17 April 2015

Revised: 16 June 2015 - Accepted: 20 June 2015 - Published: 24 July 2015

\begin{abstract}
This study focuses on physiochemical processes occurring in a brittle-ductile shear zone at both fluid-present and fluid-limited conditions. In the studied shear zone (Wyangala, SE Australia), a coarse-grained two-feldsparquartz-biotite granite is transformed into a medium-grained orthogneiss at the shear zone margins and a fine-grained quartz-muscovite phyllonite in the central parts.
\end{abstract}

The orthogneiss displays cataclasis of feldspar and crystalplastic deformation of quartz. Quartz accommodates most of the deformation and is extensively recrystallized, showing distinct crystallographic preferred orientation (CPO). Feldspar-to-muscovite, biotite-to-muscovite and albitization reactions occur locally at porphyroclasts' fracture surfaces and margins. However, the bulk rock composition shows very little change in respect to the wall rock composition. In contrast, in the shear zone centre quartz occurs as large, weakly deformed porphyroclasts in sizes similar to that in the wall rock, suggesting that it has undergone little deformation. Feldspars and biotite are almost completely reacted to muscovite, which is arranged in a fine-grained interconnected matrix. Muscovite-rich layers contain significant amounts of fine-grained intermixed quartz with random CPO. These domains are interpreted to have accommodated most of the strain. Bulk rock chemistry data show a significant increase in $\mathrm{SiO}_{2}$ and depletion in $\mathrm{NaO}$ content compared to the wall rock composition.

We suggest that the high- and low-strain microstructures in the shear zone represent markedly different scenarios and cannot be interpreted as a simple sequential development with respect to strain. Instead, we propose that the microstructural and mineralogical changes in the shear zone centre arise from a local metasomatic alteration around a brit- tle precursor. When the weaker fine-grained microstructure is established, the further flow is controlled by transient porosity created at (i) grain boundaries in fine-grained areas deforming by grain boundary sliding (GBS) and (ii) transient dilatancy sites at porphyroclast-matrix boundaries. Here a growth of secondary quartz occurs from incoming fluid, resulting in significant changes in bulk composition and eventually rheological hardening due to the precipitation-related increase in the mode and grain size of quartz. In contrast, within the shear zone margins the amount of fluid influx and associated reactions is limited; here deformation mainly proceeds by dynamic recrystallization of the igneous quartz grains.

The studied shear zone exemplifies the role of syndeformational fluids and fluid-induced reactions on the dominance of deformation processes and subsequent contrasting rheological behaviour at micron to metre scale.

\section{Introduction}

The brittle-ductile transition zone (BDTZ) represents the strongest part of the Earth's crust (Kohlstedt et al., 1995), the main seismogenic layer (e.g. Sibson, 1982; Scholz, 2007), and is a major source and transport region for ore-forming fluids (e.g. Kolb et al., 2004). However, it is also the leastunderstood part of the continental crust, where the rheological strength estimates and assumptions of rock deformation mechanisms vary widely.

BDTZ is defined as a transitional layer between the pressure-dependent brittle rheology of the upper crust and thermally activated viscous creep in the lower crust (Handy et 
al., 2007). Highly localized shear zones control deformation at this depth. The strength of BDTZ is often estimated using power-law rheology of quartz, which is the weakest and most abundant phase in granitic assemblages. Experimental data demonstrate that power-law creep in quartz can be activated at temperatures as low as $300^{\circ} \mathrm{C}$, while feldspar, being another abundant mineral in granitoids, has a high frictional strength up to temperatures of $500{ }^{\circ} \mathrm{C}$ (Passchier and Trouw, 2005).

However, in nature, brittle-ductile shear zones are often found to be altered by syn-tectonic fluids (e.g. McCaig et al., 1990; Goncalves et al., 2012; Wintsch and Yeh, 2013). The chemical and physical consequences of fluid-rock interaction have been subject of many studies demonstrating the major effects fluid has on rock rheology. Infiltration of pressurized fluid can cause brittle failure even at high confining pressures (Byerlee, 1990), allowing frictional deformation at high temperatures and low differential stresses. An increasing number of field studies recognize fluid-induced brittle precursors as the main cause for shear zone nucleation in the middle crust (Pennacchioni and Mancktelow, 2007; Fusseis and Handy, 2008; Menegon et al., 2008; Menegon and Pennacchioni, 2010; Kilian et al., 2011; Brander et al., 2012). The fluid presence in brittle-ductile shear zones is typically associated with a variety of weakening mechanisms: (1) chemical breakdown of feldspars into weak hydrous minerals (White and Knipe, 1978; Hippertt, 1998; Oliot et al., 2014); (2) reaction-controlled grain size reduction by growth of finegrained metasomatic assemblages (White and Knipe, 1978; Kilian et al., 2011); (3) switch of the dominant deformation mechanisms from solid state power-law rheology to fluidfacilitated Newtonian flow (Menegon et al., 2008; Wintsch and Yi, 2002; Brander et al., 2012); and (4) hydrolytic weakening in minerals deforming by crystal-plastic mechanisms (Tullis and Yund, 1980; Karato et al., 1986). Based on these observations the strength of the BDTZ is suspected to be orders of magnitude lower compared to the estimates from the quartz-based rheology (Bos and Spiers, 2002; Mariani et al., 2006; Park et al., 2006; Marsh et al., 2009). However, the particular role and contribution of each weakening mechanism is still under debate.

Another incompletely understood problem is the mechanism of the generation of fluid pathways in middle crust. As pointed out by Mancktelow (2006), the fact that fluid flows into and along shear zones, rather than being expelled, requires a brittle component and local pressure drops during deformation. This conclusion has led to a concept of a dynamic porosity suspected to exist even at high lithostatic pressures. The recent work by Fusseis and collaborators (Fusseis et al., 2009; Menegon et al., 2015) highlights the importance of deformation in maintaining fluid pathways in the crust. At the same time, the study by Billia et al. (2013) provides potentially direct observations of a significant intergranular porosity within brittle-ductile shear zone fabrics, suggesting high dynamic permeability during deformation.
In many cases the difference between fluid-abundant and fluid-limited/absent conditions is difficult to assess in natural shear zones. Often only one of the two scenarios is preserved. This study takes advantage of the occurrence of fluidfacilitated and fluid-restricted deformation within the same brittle-ductile shear zone, providing the opportunity to discern the particular microstructural changes and rheological effects caused by syn-tectonic fluids. Our results demonstrate the microstructural and rheological difference in each case and reveal the interplay between the dynamics of fluid flux, deformation mechanism and strain localization within the middle crust.

\section{Geological setting}

\subsection{Regional geology}

The studied shear zone belongs to the Wyangala shear zone system, which is developed within the Wyangala batholith, situated in the Eastern Lachlan Fold belt (Fig. 1), one of the three structural regions in the Lachlan orogeny, SE Australia (Gray, 1997). The Eastern Lachlan Fold belt consists of voluminous granitic to granodioritic plutons and mafic volcanics, quartz-rich turbidites, carbonates and shales (Vandenberg and Stewart, 1992). The regional tectonic reconstructions suggest that the Lachlan orogeny formed during an accretion of a volcanic island arc along the eastern margin of Gondwana 450 to $340 \mathrm{Ma}$ in a back-arc or fore-arc basin during a rifting phase in the Ordovician (Foster et al., 2009).

The Eastern Lachlan subprovince displays characteristic $\mathrm{N}-\mathrm{S}$-trending, eastward-dipping fault-thrust systems (Glen, 1992; Gray, 1997). The plutons are elongated parallel to these fault systems. Narrow contact aureoles in the host rock and undeformed margins of the plutons are considered to support a passive emplacement along pre-existing fault planes (Paterson and Tobisch, 1992; Paterson et al., 1990). The crystallization ages of the plutons in the Eastern Lachlan province are estimated from geochronological studies and show a range between 435 and $425 \mathrm{Ma}$ (Lennox et al., 2005; Squire and Crawford, 2007). The recent zircon Sensitive High-Resolution Ion Microprobe (SHRIMP) U-Pb study by Lennox et al. (2014) dates the crystallization of the Wyangala granite as late Silurian $(425.2 \pm 3.5 \mathrm{Ma})$.

Smaller-scale shear zones overprinting the major fault system are seen along the eastern margins of the granitic plutons. These are westward-dipping, generally $\mathrm{N}-\mathrm{S}$-trending and indicate a west-over-east sense of shear (Paterson et al., 1990). The Wyangala shear zone system belongs to one such structure, located on the eastern margin of the Wyangala granite. The main shearing event for these shear zones is estimated by the $\mathrm{Ar}-\mathrm{Ar}$ method using recrystallized K-feldspar (Lennox et al., 2014) to have occurred 375-365 Ma, corresponding to the late Devonian Tabberabberan deformation event. 


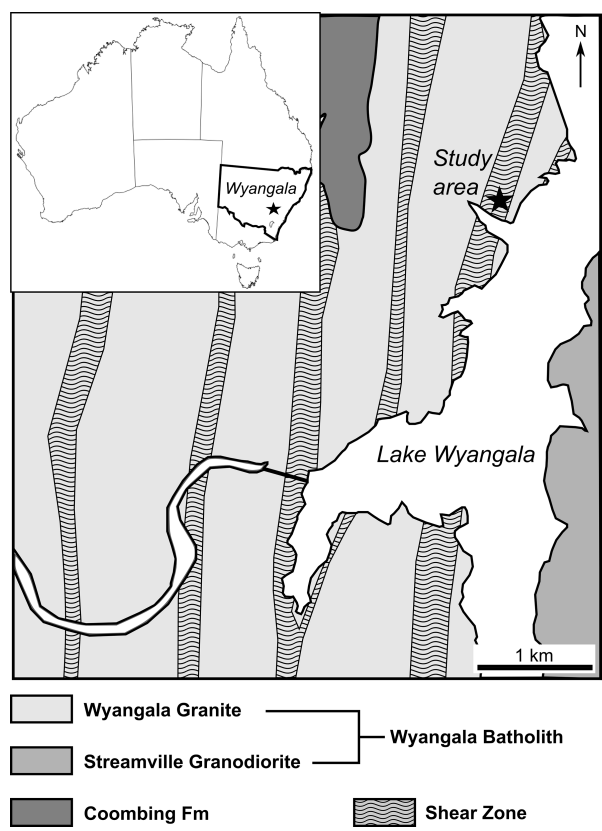

Figure 1. Locality map showing the position of Wyangala area in a regional context (inset) and the location of the studied outcrop on a simplified geological map (modified after Czarnota, 2002).

\subsection{Outcrop and general sample description}

The study area is located in the vicinity of Wyangala Dam about $25 \mathrm{~km} \mathrm{SE}$ of Cowra, NSW $\left(33^{\circ} 56.855^{\prime} \mathrm{S}\right.$ and $148^{\circ} 57.982^{\prime}$ E; Fig. 1). The outcrop exposes a weakly to strongly deformed granitic massif. The wall rock is a weakly foliated monzogranite with up to $8 \mathrm{~cm}$ large feldspar phenocrysts, quartz filling the interstices and biotite marking the incipient, discontinuous foliation planes (Fig. 2c).

Based on the structural and mineralogical properties we distinguish 2 domains within the studied shear zone: (1) orthogneiss in the shear zone margins and (2) phyllonite in the central part. The transition from the wall rock into orthogneiss occurs over a $0.5-1 \mathrm{~m}$ distance, characterized by a gradual decrease in grain sizes and a development of a thin-spaced, continuous foliation, defined by phyllosilicates. Feldspar grains become more fragmented towards the shear zone centre, and quartz is more and more arranged in elongated lenses or layers (Fig. 2a, c).

The boundary between the orthogneiss and phyllonite is sharp and marked by a sudden strengthening of foliation and disappearance of feldspar grains (Fig. 2a, c). The central domains display centimetre- to millimetre-scale alteration between two types of phyllonites (Fig. 2b). Phyllonite A is composed of fine, muscovite-dominated matrix surrounding large, elongated quartz grains. These large quartz grains in phyllonite A have similar sizes to quartz in the wall rock. Phyllonite B contains more quartz than phyllonite A but has a larger matrix mode and exhibits higher phase mixing (Fig. 2c).

In total 9 samples were collected from all distinguished lithologies, representing wall rock, orthogneiss and both types of phyllonite.

\section{Methods}

\subsection{Sample selection and preparation}

Samples were cut perpendicular to the foliation ( $y z$ plane) and parallel to the stretching lineation ( $x$ axis) and polished down to $\sim 30 \mu \mathrm{m}$ thickness for thin sections. In total 16 thin sections were prepared for detailed optical and chemical analysis. For electron backscatter diffraction (EBSD) analysis a colloidal silica-water solution (mixed in proportion $80: 20$ ) was used at the final stage of polishing for 3-5 min to reduce surface damage produced by mechanical polishing. All thin sections were carbon-coated for scanning electron microscopy (SEM) analysis.

In order to ensure comparability, all quantitative analysis, including X-ray fluorescence (XRF), EBSD, point counting and image analysis were carried out on the same 4 selected samples, representing each shear zone domain (W17 - wall rock; W13b - orthogneiss; W21b - phyllonite A; W21c phyllonite B). Their locations are given in Fig. 2a, b.

The mineral abbreviations used in the following sections follow the recommendations of Kretz (1983).

\subsection{Mineral chemistry and cathodoluminescence $(C L)$ imaging}

The chemical composition of the rock-forming minerals was determined using energy dispersive spectrometry (EDS) on a Carl Zeiss IVO SEM at the Geochemical Analysis Unit (GAU, Macquarie University), using the AzTec software from Oxford Instruments. The analytical accuracy of anhydrous phases, such as feldspars, is 0.1 to $0.2 \mathrm{wt} \%$. The analyses were performed at high-vacuum conditions with an accelerating voltage of $15-20 \mathrm{kV}$, with a beam current of $5.0-10.0 \mathrm{nA}$ at working distances from 12 to $12.5 \mathrm{~mm}$. The same operating conditions, except for the accelerating voltage which was kept at $15 \mathrm{kV}$, were used for cathodoluminescence (CL) imaging of quartz microstructures.

\subsection{Orientation analysis and data processing}

Crystallographic orientation data were acquired using HKL NordlysNano high-sensitivity Electron Backscatter Diffraction (EBSD) detector and indexed with AzTec analysis software (Oxford Instruments) at the Geochemical Analysis Unit (GAU, Macquarie University). The analyses were carried out on a sample tilted to $70^{\circ}$ angle, in high-vacuum conditions with $20 \mathrm{kV}$ accelerating voltage and a beam current of $8.2 \mathrm{nA}$, at working distances from 9 to $13 \mathrm{~mm}$. The typical 


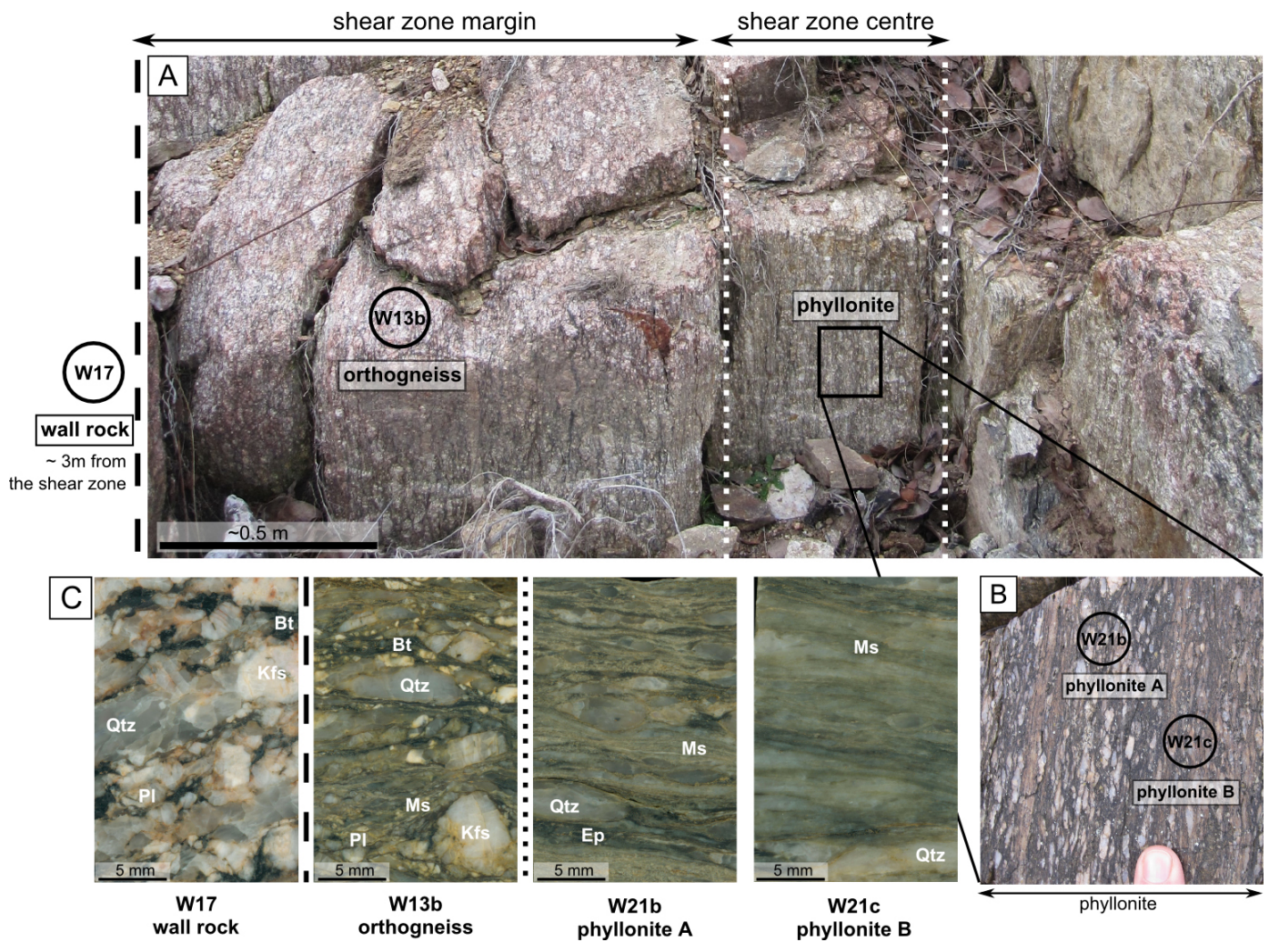

Figure 2. Outcrop and hand specimens. (a) Photo of the studied outcrop showing the different shear zone domains and collection sites of four studied representative samples (W17; W13b; W21b; W21c), which were further used for all the quantitative analysis; (b) fine-scale alternation between phyllonite A and phyllonite B in the central part of the shear zone; (c) sequence of representative samples collected in a transect across the shear zone.

step sizes ranged from 1 to $5 \mu \mathrm{m}$, depending on the required resolution and the average grain size in the region of interest. Simultaneously with EBSD data, EDS data were collected to assist with the phase determination during post-processing of the acquired data.

Channel 5 analysis software from HKL Technology was used for the post-acquisition processing of the stored EBSD patterns. The obtained EBSD maps contained from 5 to $26 \%$ of non-indexed points (zero solutions), mostly resulting from the difficulty to index phyllosilicates. The map quality was first improved by a "standard" noise reduction following the procedure of Prior et al. (2002) and Bestmann and Prior (2003). The second step included the removal of "fake grains" (all grains with area smaller than a squared step size), where grains were determined by a minimum grain boundary angle of $10^{\circ}$ and subgrains were defined by a boundary angle of $2-10^{\circ}$ in intra-grain regions. After the processing procedure, indexing in all maps except for one exceeded $80 \%$ and was close to $100 \%$ for quartz-dominated areas.

Pole figures were calculated using one point per grain, and plotted on the upper-hemisphere equal-area projections with stretching lineation parallel to the $x$ axis and foliation normal to the $z$ axis. All maps and data sets were rotated consistent with a dextral shear sense as determined by asymmetry of quartz orientations. In the field it was not possible to determine shear sense unequivocally.

\subsection{Modal composition}

The modal amounts of mineral phases (Fig. 3a) were determined using the point-counting method for the four representative thin sections. A minimum of 1000 points for each thin section were counted. Modal amounts of quartz microstructures (Fig. 3b) were estimated on the same four thin sections using manually outlined optical micrographs and the imaging software Image J (http://imagej.nih.gov/ij/index.html). As one quartz microstructure ( $\mathrm{Qtz}_{3}$; details in the following) is very fine grained and occurs in mixtures with muscovite, it could not be quantified directly and thus was estimated by subtracting the sum of the other two quartz microstructure modes $\left(\mathrm{Qtz}_{1}+\mathrm{Qtz}_{2}\right.$; details in the following) from the total quartz mode determined by point counting.

\subsection{Whole-rock analysis}

Bulk whole-rock major-, minor- and trace-element concentrations were measured by XRF analysis for the four chosen representative samples from each shear zone domain 


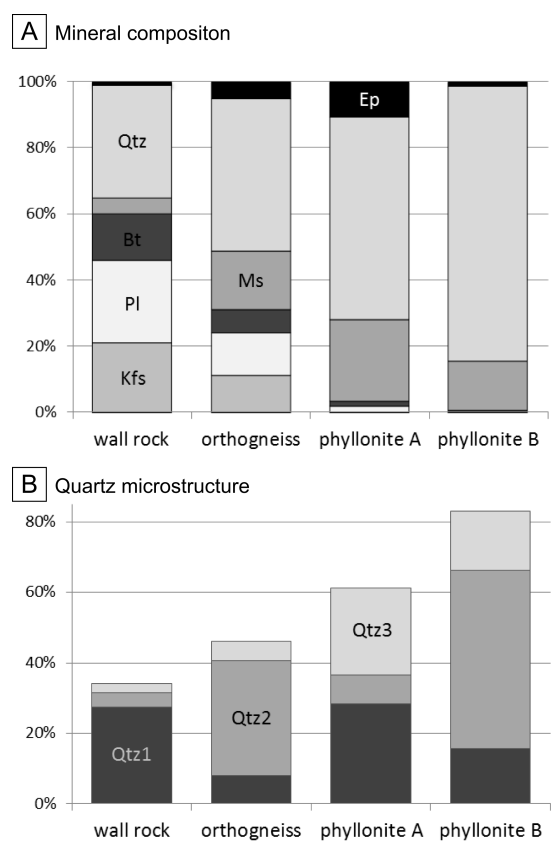

Figure 3. (a) Measured modal mineral compositions of each shear zone domain (Kfs - K-feldspar; Pl - plagioclase; Bt - biotite; Ms - muscovite; Qtz - quartz; Ep - epidote). (b) The estimated modal amounts of different quartz microstructures in each shear zone domain (see text for details).

(Fig. 2a). Samples were processed into fine powders and analysed with a PANalytical PW2400 Sequential WDXRF Spectrometer at the University of New South Wales. Obtained data sets are presented in Table A1.

\subsection{Isocon method}

To quantitatively evaluate the mass transfer between the shear zone domains, we used the isocon method by Grant (1986) based on the composition-volume equations proposed by Gresens (1967). It allows estimating the absolute change in the concentration for each individual oxide using the following equation:

$\Delta M_{j}=\left(\left(\frac{C_{i}^{p}}{C_{i}^{a}}\right)\left(\frac{C_{j}^{a}}{C_{j}^{p}}\right)-1\right) \times 100$,

where $\Delta M$ is the mass change in percent; $(C)$ is concentration; superscripts $(p)$ and $(a)$ stand for protolith and altered sample; subscripts $(i)$ and $(j)$ stand for immobile and mobile elements.

The slope of the isocon $\left(S=\left(C_{i}^{a} / C_{i}^{p}\right)\right.$ reflects the total mass difference between each two analysed samples. The absolute change in the total mass (in \%) thus was estimated using the equation

$\Delta M_{\mathrm{total}}=\left(\left(\frac{1}{S}\right)-1\right) \times 100$.
For the isocon construction and calculations we assumed the immobility of aluminium $\left(\mathrm{Al}_{2} \mathrm{O}_{3}\right)$ as (i) it has been shown to be immobile during the deformation of granitoids in greenschist facies shear zones (Eilu et al., 2001; Rolland et al., 2003) and (ii) it is consistent with microstructural observations in the studied samples.

\section{Results}

\subsection{Optical microstructures, phase abundance and mineral chemistry}

\subsubsection{Wall rock: weakly foliated monzogranite}

The wall rock consists of $34 \%$ quartz, $25 \%$ plagioclase, $21 \% \mathrm{~K}$-feldspar, $14 \%$ biotite, $5 \%$ muscovite and $<1 \%$ accessory minerals (zoesite, apatite, chlorite, zircons and Fe-Ti oxides) (Fig. 3a).

The most typical quartz microstructure in the wall rock, further referred to as $\mathrm{Qtz}_{1}$ (Fig. 3b, 4), is characterized by up to $5 \mathrm{~mm}$ long grains with anhedral, equidimensional or slightly elongated shapes having aspect ratios of $\sim 1$ to 1.5. Intracrystalline deformation features such as undulose extinction and deformation lamellae are common in these grains; subgrains occur occasionally. Quartz additionally occurs as fine-grained, largely monocrystalline aggregates associated with Qtz 1 grains (Fig. 4a). These microstructures are referred to in the following as $\mathrm{Qtz}_{2}$. In the wall rock $\mathrm{Qtz}_{2}$ constitutes only a minor amount (Fig. 3b).

Plagioclase and K-feldspar in the wall rock typically occur as $5-8 \mathrm{~mm}$ large, euhedral or subhedral grains, referred to as $\mathrm{Pl}_{1}$ and $\mathrm{Kfs}_{1}$, respectively (Fig. 4). $\mathrm{Pl}_{1}$ displays normal compositional zoning characterized by $\mathrm{Ca}$-enriched cores $\left(a_{59-81}\right)$ and Na-rich rims $\left(a_{92-94}\right)$. The cores are heavily altered to fine-grained muscovite, K-feldspar and epidote, while the rims rarely contain inclusions. Intergrown clusters of two or three $\mathrm{Pl}_{1}$ grains are common. Euhedral $\mathrm{Pl}_{1}$ grains occasionally occur in the interiors of larger $\mathrm{Kfs}_{1}$ grains. All $\mathrm{Kfs}_{1}\left(\right.$ or $\left._{96-100}\right)$ are perthitic, with albite (ab $\left.{ }_{96-98}\right)$ lamellae covering about $20 \%$ of the grain area (Fig. 4b, c). These grains often exhibit fragmentation and pull-apart fractures filled with fibrous or blocky quartz and biotite. The individual fragments of $\mathrm{Kfs}_{1}$ however are not significantly displaced with respect to each other.

Biotite $\left(\mathrm{Bt}_{1}\right)$ is the dominant phyllosilicate in the wall rock assemblage (Fig. 3a) and occurs as up to $5 \mathrm{~mm}$ long grains (Fig. 4a). Rarely, up to $3 \mathrm{~mm}$ long muscovite $\left(\mathrm{Ms}_{1}\right)$ grains can also be seen in the wall rock (Fig. 4c). Typically phyllosilicates display well-developed cleavage and minor kinking and fracturing. Apatite and zircon occur as inclusions in $\mathrm{Bt}_{1}$ grains. 


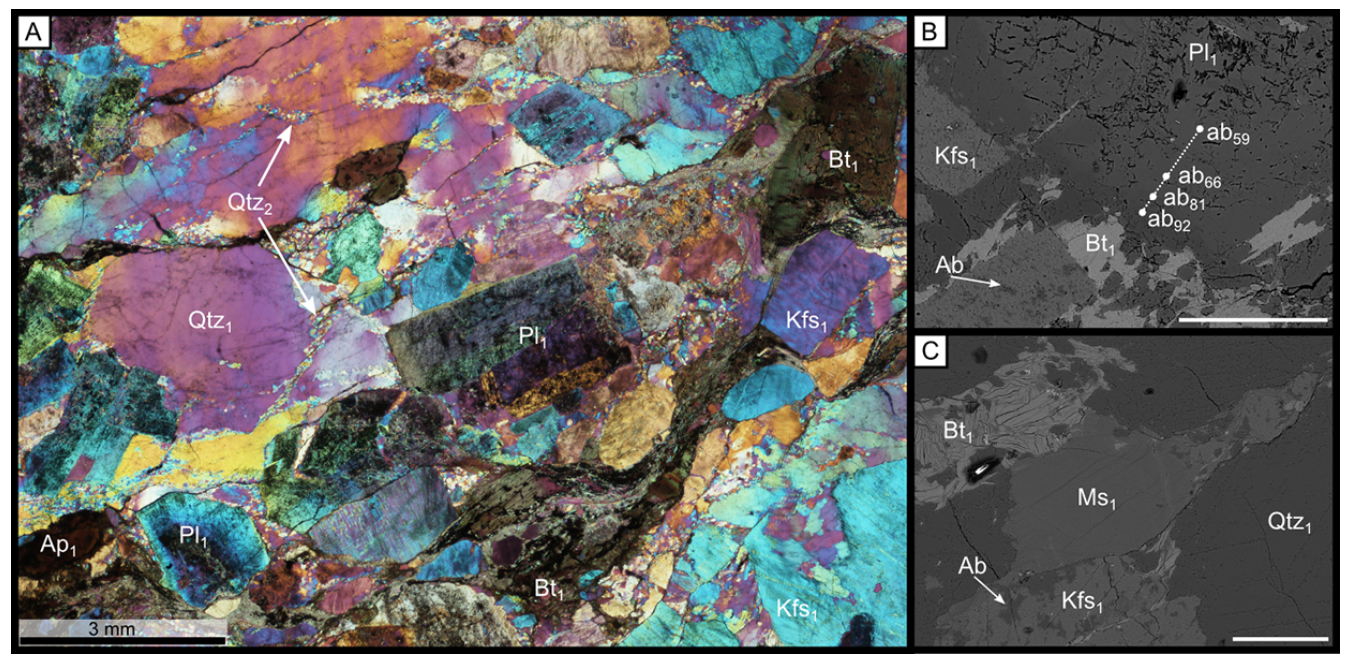

Figure 4. Typical microstructures and mineral assemblages in the wall rock; scale bar for (b)-(c) is $200 \mu \mathrm{m}$. (a) Optical micrograph (crossed polarizers with gypsum plate inserted) showing undulose extinction in quartz $\left(\mathrm{Qtz}_{1}\right)$, transecting Qtz $\mathrm{Q}_{1}$ grains, euhedral feldspar grains $\left(\mathrm{Pl}_{1}\right.$, $\mathrm{Kfs}_{1}$ ) and $\mathrm{Bt}_{1}$. Arrows points to developing Qtz 2 domains, which often associate with Qtz 1 grains; (b) BSE image showing compositional zonation in plagioclase $\mathrm{Pl}_{1}$ and albite exsolution lamellae in $\mathrm{Kfs}_{1}$; (c) BSE image showing the microstructure of the igneous phyllosilicates $\left(\mathrm{Bt}_{1}\right.$ and $\left.\mathrm{Ms}_{1}\right)$ characterized by large cleaved and kinked grains.

\subsubsection{Shear zone margin: orthogneiss}

The orthogneiss is composed of $46 \%$ quartz, $18 \%$ muscovite, $13 \%$ plagioclase, $11 \% \mathrm{~K}$-feldspar, $7 \%$ biotite and $5 \%$ epidote (Fig. 3a).

Up to $70 \%$ of quartz in this domain (Fig. 3b) is represented by the fine-grained $\mathrm{Qtz}_{2}$ aggregates (Fig. 5a, c, f). The average sizes of $\mathrm{Qtz}_{2}$ grains are between 15 and $25 \mu \mathrm{m}$; the grains have aspect ratios of about 1.8 and display a shapepreferred orientation $(\mathrm{SPO})$. Qtz $\mathrm{Qt}_{1}$-type grains are rare $(\sim 8 \%$ of all quartz) and commonly surrounded by mantles of $\mathrm{Qtz}_{2}$ aggregates. Qtz 1 grains are typically up to $1 \mathrm{~cm}$ long, with aspect ratios between 3 and 4, and display undulose extinction, subgrains, slightly serrated boundaries and intragranular bands and patches of $\mathrm{Qtz}_{2}$ aggregates (Fig. 5a, f). Another quartz microstructure referred to in the following as $\mathrm{Qtz}_{3}$ can be distinguished in the orthogneiss (Fig. 3b). It is characterized by very fine grain sizes and often intermixed with finegrained muscovite (Fig. 5a, d, e). Here, it is mainly seen in strain shadows of feldspar grains.

Both plagioclase and K-feldspar form up to about $3 \mathrm{~mm}$ long grains with aspect ratios of 1.5-1.8. Due to the microstructural and chemical similarity with feldspars in the wall rock, we refer to them as $\mathrm{Pl}_{1}$ and $\mathrm{Kfs}_{1}$. Both, $\mathrm{Pl}_{1}$ and $\mathrm{Kfs}_{1}$ occur in association with fine-grained muscovite $\left(\mathrm{Ms}_{2}\right)$ mantles (Fig. 5a-e). While $\mathrm{Pl}_{1}$ grains tend to have rounded and irregular shapes, $\mathrm{Kfs}_{1}$ forms clusters of angular grains and display intragranular fractures, rotated fragments, bookshelf structures and pull-aparts. The fractures and strain shadows of feldspar grains are filled with a nonperthitic K-feldspar, further referred to as $\mathrm{Kfs}_{2}$; fine-grained albitic plagioclase ( $\left.\mathrm{ab}_{95}-99\right)$, referred to as $\mathrm{Pl}_{2}$; fine-grained quartz (Qtz 3 ) and muscovite ( $\left.\mathrm{Ms}_{2}\right)$ mixtures (Fig. 5d, e).

Phyllosilicates in the orthogneiss are mostly represented by $\mathrm{Ms}_{2}$ (Fig. 3a). Biotite and epidote are commonly present in the $\mathrm{Ms}_{2}$-rich bands but are not in direct contact with feldspar grains.

\subsubsection{Shear zone centre: phyllonite A}

The mineralogy of phyllonite $\mathrm{A}$ is dominated by quartz $(62 \%)$, muscovite $(25 \%)$ and epidote $(11 \%)$, with minor amounts of plagioclase $(\sim 1.7 \%)$ and biotite $(\sim 1.4 \%)$ (Fig. 3a).

$\mathrm{Qtz}_{1}$ grains are larger than in the orthogneiss, approaching sizes comparable to $\mathrm{Qtz}_{1}$ in the wall rock (Fig. 6a). They are typically elongated with aspect ratios close to 4 and length up to $8 \mathrm{~mm}$. Intracrystalline deformation structures - including undulose extinction, subgrains and deformation lamellae - are common. Fine-grained aggregates of $\mathrm{Ms}_{2}, \mathrm{Qtz}_{3}, \mathrm{Ep}_{2}$ and $\mathrm{Pl}_{2}$ form thick layers around $\mathrm{Qtz}_{1}$ grains. In some parts this matrix can consist of up to $70 \%$ of very fine $\mathrm{Qtz}_{3}$-type grains with average grain sizes of about 5-8 $\mu \mathrm{m}$ and aspect ratios of 1.8-1.9. The tails of $\mathrm{Qtz}_{1}$ grains commonly consist of mixtures of fibre-shaped Qtz $3-\mathrm{Ms}_{2}$ (Fig. 6d).

The monomineralic, fine-grained aggregates of $\mathrm{Qtz}_{2}$ in phyllonite A constitute only $13 \%$ of the total quartz mode, in contrast to the high abundances in the orthogneiss (Fig. 3b). They show a similar relationship to $\mathrm{Qtz}_{1}$ grains as in orthogneiss but do not form thick mantles.

Feldspars are represented by up to $1 \mathrm{~mm}$ large Na-rich $\left(\mathrm{ab}_{97-100}\right)$ plagioclase $\left(\mathrm{Pl}_{2}\right)$ grains (Fig. 6a, c). They are commonly surrounded by $\mathrm{Ms}_{2}$-rich matrix and epidote clus- 


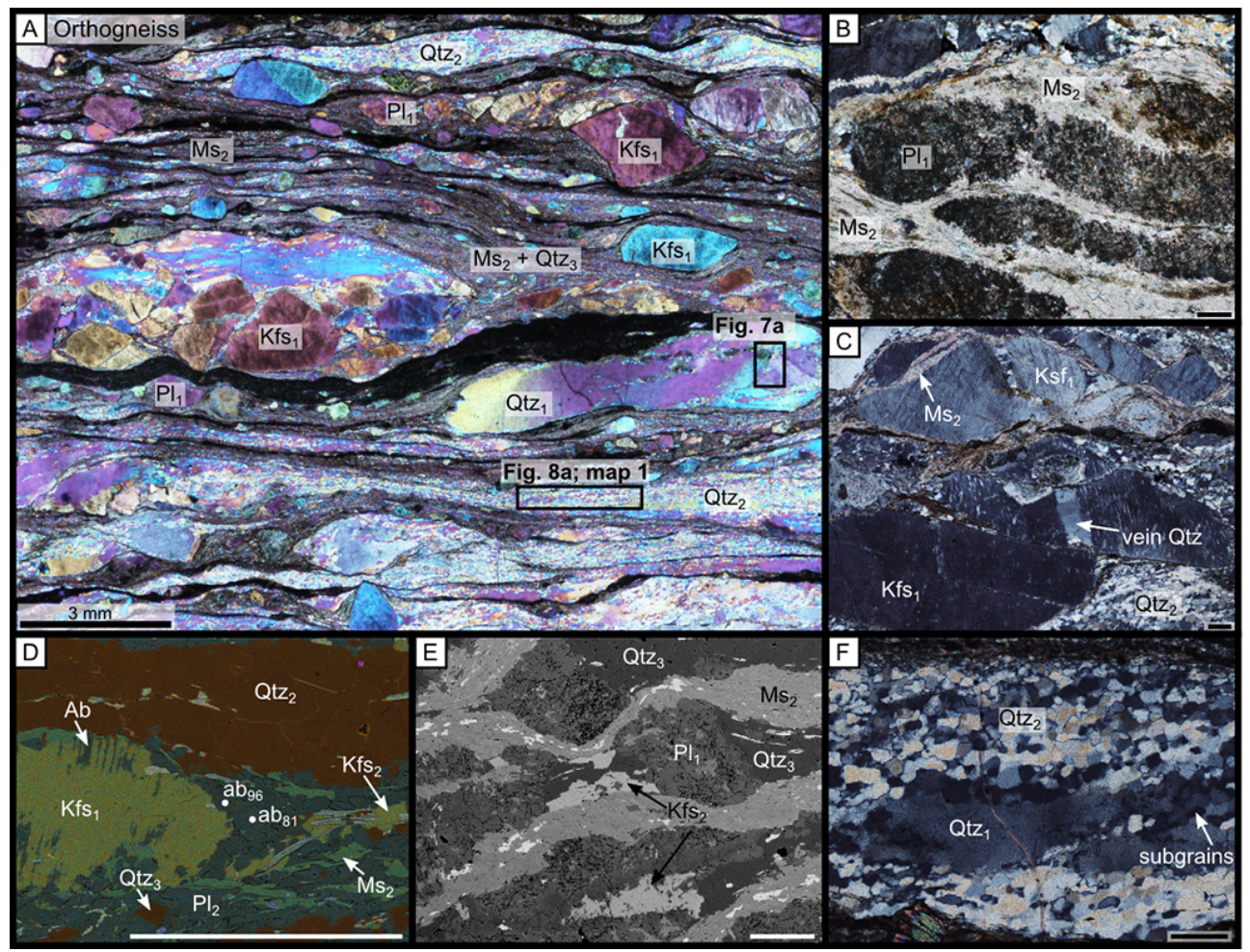

Figure 5. Typical microstructures and mineralogy in orthogneiss; scale bar for (b)-(f) is $200 \mu \mathrm{m}$. (a) Optical micrograph (crossed polarizers with gypsum plate inserted) showing large fractured feldspar grains $\left(\mathrm{Kfs}_{1}\right.$ and $\left.\mathrm{Pl}_{1}\right)$; undulose extinction in quartz (Qtz $)$; fine-grained, monomineralic domains of $\mathrm{Qtz}_{2}$; and thin, muscovite-rich mantles surrounding $\mathrm{Kfs}_{1}$ and $\mathrm{Pl}_{1}$. (b) Optical micrograph (crossed polarizers) showing fine-grained muscovite $\left(\mathrm{Ms}_{2}\right)$ corona around plagioclase $\left(\mathrm{Pl}_{1}\right)$. (c) Optical micrograph (crossed polarizers) showing book-shelf fractures in K-feldspar $\left(\mathrm{Kfs}_{1}\right)$ and muscovite $\left(\mathrm{Ms}_{2}\right)$ aggregates associated with fractures and grain boundaries. (d) EDX- derived compositional map showing $\mathrm{Kfs}_{1}$ grain with albite exsolution lamellae and $\mathrm{Pl}_{2}, \mathrm{Qtz}_{3}, \mathrm{Kfs}_{2}$ and $\mathrm{Ms}_{2}$ in the strain shadow, where the small plagioclase grains have variable compositions typically having oligoclase cores and albite rims. (e) $\mathrm{BSE}$ image showing $\mathrm{Pl}_{1}$ porphyroclasts with $\mathrm{Qtz}_{3}$ and $\mathrm{Kfs}_{2}$ in the strain shadows and $\mathrm{Ms}_{2}$ forming strain caps. (b) Optical micrograph (crossed polarizers) showing Qtz 1 grain surrounded by Qtz 2 aggregates. Qtz 1 displays undulose extinction and subgrains exhibiting similar sizes to Qtz2 grains.

ters and display well-pronounced, parallel fracture sets filled by $\mathrm{Ms}_{2}$. Some of the $\mathrm{Pl}_{2}$ grains are twinned and have undulose extinction.

\subsubsection{Shear zone centre: phyllonite B}

Samples from phyllonite B are mainly composed of quartz $(83 \%)$ and muscovite $(15 \%)$, with small amounts of epidote $(\sim 1.5 \%)$, biotite $(\sim 0.3 \%)$ and minor plagioclase $(\sim 0.1 \%)$ (Fig. 3a).

The microstructure in phyllonite B consists of centimetreto millimetre-scale alternating bands of mixed, fine-grained aggregates of $\mathrm{Qtz}_{3}-\mathrm{Ms}_{2}$. Variations in the modal amounts of the two phases characterize the layering (Fig. 6b, g). $\mathrm{Ms}_{2}$ grains are typically $10-20 \mu \mathrm{m}$ in length, aligned subparallel to the main foliation and homogenously mixed with $\mathrm{Qtz}_{3}$. Muscovite-poor layers display typical $\mathrm{Qtz}_{1}-\mathrm{Qtz}_{2}$ associations, similar to the ones in orthogneiss, with elongated up to $5 \mathrm{~mm}$ long $\mathrm{Qtz}_{1}$ grains in the central parts, surrounded by mantles of the fine-grained $\mathrm{Qtz}_{2}$. In muscovite-rich do- mains, very fine grained $\mathrm{Qtz}_{3}$ is homogenously intermixed with fine-grained $\mathrm{Ms}_{2}$. The grain size of $\mathrm{Qtz}_{3}$ depends on the $\mathrm{Ms}_{2}$ amount present (Fig. 6g). It varies from $8 \mu \mathrm{m}$ in domains with $30 \%$ muscovite to $20 \mu \mathrm{m}$ in domains with $5 \% \mathrm{Ms}_{2}$.

\subsection{Crystallographic orientation analysis}

Crystallographic preferred orientation (CPO) analysis focuses on quartz microstructure. No EBSD analysis is necessary for muscovite, where $c$ axis is perpendicular to the elongation of the grain, and the majority of the grains display well-pronounced elongation parallel to the general foliation. Feldspars show dominantly brittle deformation; thus no specific crystallographic orientation data were sought for these. In the following, we characterize in detail the different quartz types as identified from optical analysis.

\subsubsection{Qtz 1 porphyroclasts}

Figure $7 \mathrm{~b}$ shows a combined pole plot for six $\mathrm{Qtz}_{1}$-type grains from all deformed shear zone domains. The bulk ori- 


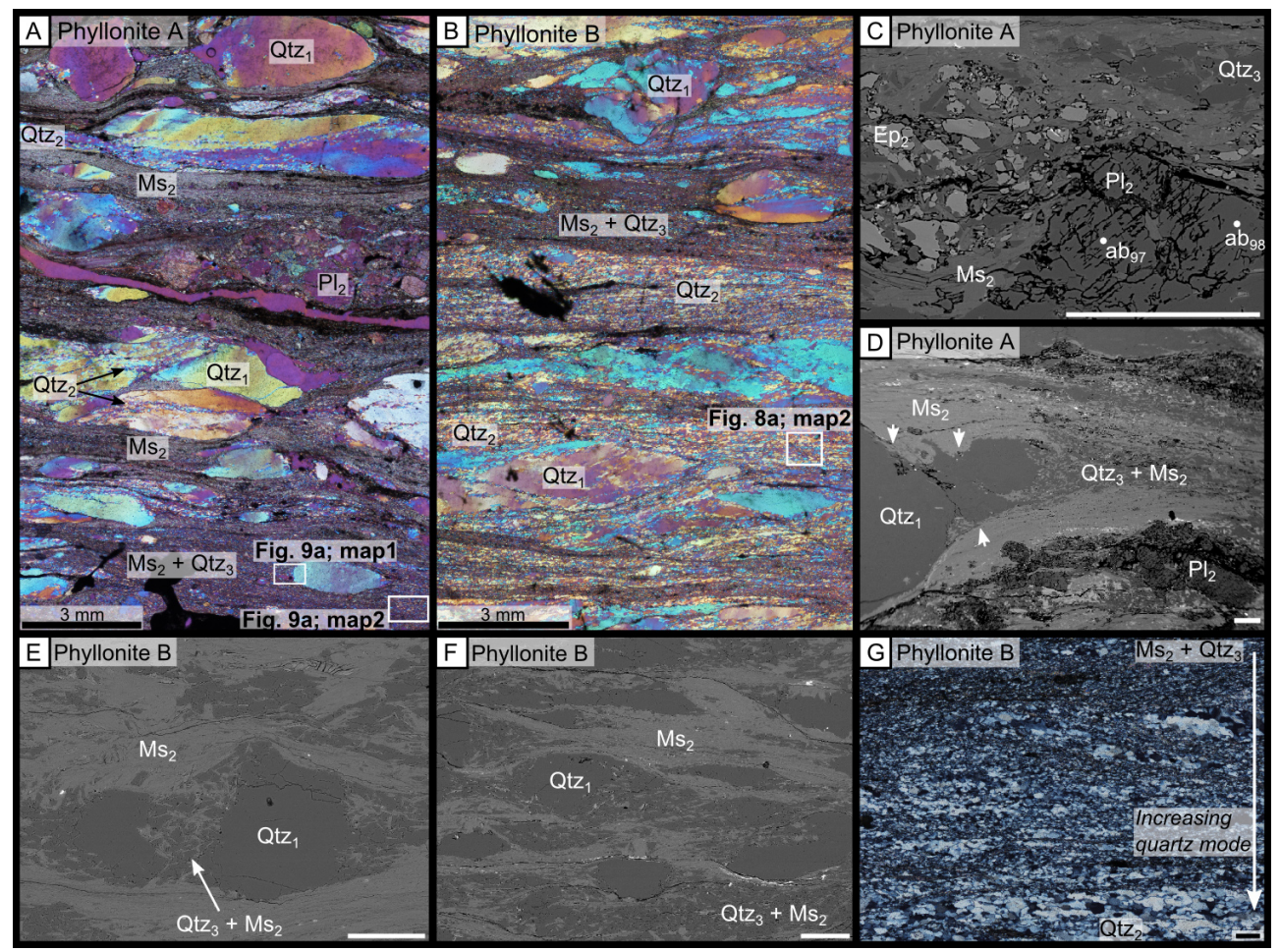

Figure 6. Typical microstructures and mineralogy in phyllonite A and B; scale bar for (b)-(g) is $200 \mu$ m. (a)-(b) Optical micrographs (crossed polarizers with gypsum plate inserted), (c)-(f) BSE images and (g) optical micrograph with crossed polarizers; (a) overview of microstructures in phyllonite A; (b) overview of microstructures in phyllonite B; (c) fractured plagioclase grain surrounded by mantle of muscovite, epidote and quartz; (d) quartz grain having irregular boundaries with muscovite (noted with arrows) and mixed quartz-muscovite layer in the strain shadow; (e) the extensional site between two $\mathrm{Qtz}_{1}$ grains filled by mixed quartz-muscovite aggregates; (f) Qtz 1 grains in muscovite-quartz matrix, showing the tendency of monomineralic muscovite layers to occur parallel to the shear direction and quartzmuscovite mixtures to occur in the strain shadows; (g) fine-grained matrix in phyllonite B showing variations of the quartz to muscovite modal amounts on the millimetre scale.

entation of these grains is non-random, with the poles of $c$ axis clustering $5-45^{\circ}$ clockwise from $z$ direction. This arrangement is consistent with the general shear sense in the analysed samples. In the second pole figure (Fig. 7b), a CPO pattern of a single strongly deformed $\mathrm{Qtz}_{1}$ grain is presented, showing the range of internal deformation in the crystal lattice. Two $c$ axis maxima appear next to the opposite poles of $z$ direction, lying on the same great circle.

Internally $\mathrm{Qtz}_{1}$ grains show a high degree of lattice distortions, with high abundance of subgrain boundaries, most of them oriented approximately at $45^{\circ}$ angles to the foliation plane (Fig. 7a). The variations of internal misorientation across a single grain can reach more than $40^{\circ}$ (Fig. 7c; profile 1). Dauphine twin boundaries, identified by the $60 \pm 2^{\circ}$ lattice rotation around the $c$ axis, are common (Fig. 7a). They typically occur as irregular patches in highly deformed internal parts or along highly stressed edges of the grains.

\subsubsection{Qtz2 aggregates}

Grain orientations in the fine-grained $\mathrm{Qtz}_{2}$ domains always display a strong CPO. In the areas surrounding $\mathrm{Qtz}_{1}$ porphy- roclasts, the $\mathrm{CPO}$ of $\mathrm{Qtz}_{2}$ grains tends to cluster close to the porphyroclast orientation, with a slight rotation towards the centre of the pole figure (Fig. 8b; map 1). In the homogenous $\mathrm{Qtz}_{2}$ domains, devoid of $\mathrm{Qtz}_{1}$ grains, the $\mathrm{CPO}$ of $\mathrm{Qtz}_{2}$ is arranged in an asymmetric Type Ia crossed-girdle pattern (Passchier and Trouw, 2005), subparallel to $z$ direction and synthetic with the shear direction (Fig. 8b; map 2).

Subgrain and Dauphine twin boundaries are common (Fig. 8a). The variations in internal misorientation angles across single grains typically range from 2 to $4^{\circ}$ but can reach up to $9^{\circ}$ misorientation in the largest grains (Fig. 8c).

\subsection{3 $\mathrm{Qtz}_{3}$ in muscovite-quartz mixtures}

Two associations of $\mathrm{Qtz}_{3}$ grains were analysed in phyllonite A and phyllonite B: one from a tail of a Qtz 1 -type grain, another from an interior of a fine-grained quartzmuscovite band (Figs. 6a, 9a). The crystallographic orientation of $\mathrm{Qtz}_{3}$ grains at the tails of $\mathrm{Qtz}_{1}$ typically cluster close to the orientation of the $\mathrm{Qtz}_{1}$ grain (Fig. 9b; map 1). Often the $\mathrm{Qtz}_{3}$ grains in these tails form string-like aggregates. Misorientation profiles across individual grains parallel to the elon- 


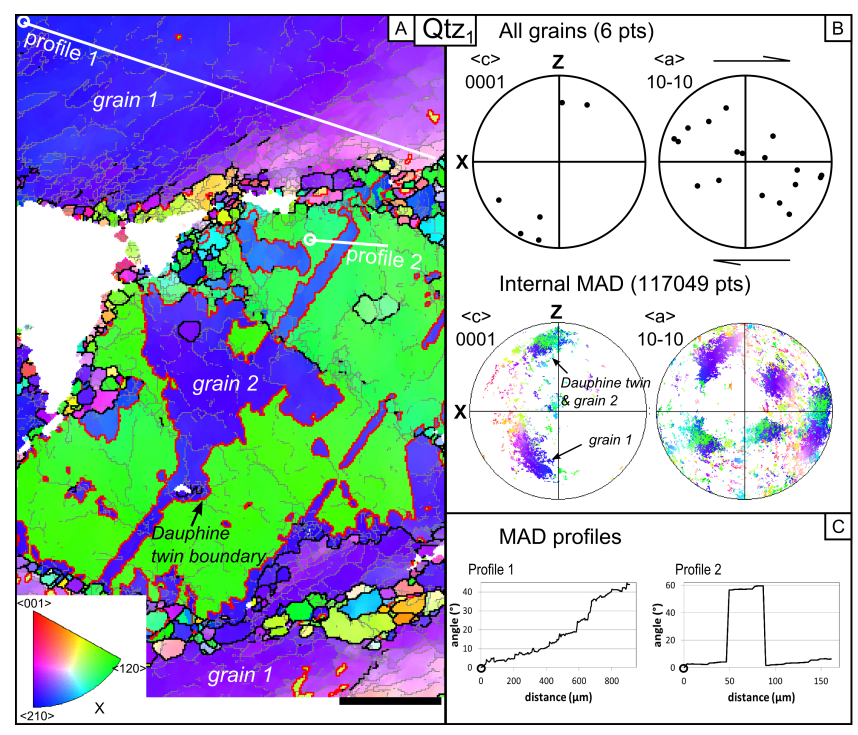

Figure 7. (a) GB (grain boundary) + IPF (inverse pole figure) map of a $\mathrm{Qtz}_{1}$ grain from orthogneiss (acquisition location marked in Fig. 5a), scale bar $200 \mu \mathrm{m}$. Subgrain boundaries are marked as grey lines, grain boundaries are black and Dauphine twin boundaries are red. White pixels are non-indexed points or other phases. (b) Pole figure plots showing the crystallographic orientations of all analysed $\mathrm{Qtz}_{1}$ grains (top) and internal misorientation angle distributions of each pixel in the map (a) (bottom). (c) Misorientation profiles across two selected regions in the map (a), where the profiles are marked with white lines and the white circle represents starting position.

gation of these "strings" do not exceed $15^{\circ}$ between adjacent grains (Fig. 9c; profile 1).

In contrast, $\mathrm{Qtz}_{3}$ grains in the matrix-forming Qtz-Ms bands display close-to-random CPO (Fig. 9b; map 2ii). Domains with smaller muscovite content may have similar, or slightly larger, grain sizes but show much stronger CPO than muscovite-rich domains (Fig. 9b, map 2i vs. map 2ii). Despite the small grain size (average $8 \mu \mathrm{m}$ ) the individual $\mathrm{Qtz}_{3}$ grains display subgrains, Dauphine twinning and lattice bending, typically ranging from 1 to $3^{\circ}$, but angles up to $13^{\circ}$ are not uncommon (Fig. 9c; profile 2).

\subsection{Cathodoluminescence (CL) microstructures}

CL pattern imaging of quartz is a commonly used, powerful technique for distinguishing multiple growth events and fluid/melt influx events in igneous (e.g. D'Lemos et al., 1997), metamorphic (e.g. Bergman and Piazolo, 2012) and sedimentary rocks (e.g. Demars et al., 1996). Accordingly, we performed CL imaging to investigate the potential difference in patterns developed in $\mathrm{Qtz}_{2}$ and $\mathrm{Qtz}_{3}$ microstructure, present in the orthogneiss and phyllonite, respectively. As shown in Fig. 11, several differences can be recognized.

The quartz in the orthogneiss was analysed from the monocrystalline $\mathrm{Qtz}_{2}$ domains, which are seen in the tails of the recrystallizing porphyroclasts. The CL image displays a polygonal structure where the lighter central areas are enclosed by darker rims (Fig. 11a). Comparison of the CL image and EBSD map, acquired from the same area, shows that the dark rims in the CL pattern coincide mainly with grain, and in some cases subgrain, boundaries (Fig. 11b).

In phyllonite $\mathrm{B}$, quartz was analysed from the fine-grained, mixed $\mathrm{Qtz}_{3}-\mathrm{Ms}_{2}$ domains. In general, the CL pattern for $\mathrm{Qtz}_{3}$ is more intricate than that of $\mathrm{Qtz}_{2}$. It consists of thin, lighter lines, cross-cutting darker quartz grains (Fig. 11c). These linear features do not represent any visible cracks or grain boundaries. Lighter and darker polygons are also seen adjacent to each other, and the variations in CL shading do not correspond to grain boundaries. In summary, the variations in the CL patterns of $\mathrm{Qtz}_{3}$, in contrast to the patterns in $\mathrm{Qtz}_{2}$, are clearly intragranular in nature (Fig. 11d, e).

\subsection{Whole-rock geochemistry}

Figure 10a shows that the chemical composition of the orthogneiss closely resembles the composition of the wall rock. The slope of the isocon approximates 1 and, all the major elements lie near to the isocon. Slight enrichment in $\mathrm{CaO}$ and depletion in $\mathrm{Mn}_{3} \mathrm{O}_{4}, \mathrm{MgO}, \mathrm{P}_{2} \mathrm{O}_{5}$ and $\mathrm{K}_{2} \mathrm{O}$ may be related to the heterogeneity of the analysed samples.

The element concentrations in phyllonite A deviate from the isocon more significantly (Fig. 10b; Table A1). $\mathrm{SiO}_{2}$ and $\mathrm{FeO}$ are enriched, reflecting the increased quartz and epidote modes in phyllonite A (Fig. 3a). All the other major elements, especially $\mathrm{Na}_{2} \mathrm{O}$, are depleted. The major loss in $\mathrm{Na}_{2} \mathrm{O}(-79 \%)$ coincides with the decrease in feldspar mode from $46 \%$ in the wall rock to $1.7 \%$ in phyllonite A (Fig. 3a). Furthermore, the isocon itself lies below the "constant mass" line (dashed line in Fig. 10), indicating a total mass increase of $12.2 \%$ compared to the wall rock domain.

Phyllonite B maintains the chemical trends displayed by phyllonite A but shows more extreme deviations from the wall rock composition (Fig. 10c; Table A1). The isocon slope of 0.29 equates to a total mass gain of $239 \%$. Large gains in $\mathrm{SiO}_{2}(+332 \%)$ concentration correspond to the increase in quartz mode from $34 \%$ in the wall rock to $83 \%$ in phyllonite $\mathrm{B}$ (Fig. 3a). $\mathrm{Na}_{2} \mathrm{O}$ again shows depletion; the near-zero concentration reflects the loss of feldspars in the shear zone centre.

\section{Discussion}

\subsection{Orthogneiss and phyllonite: same protolith, or not?}

The studied shear zone displays two mineralogically and structurally different domains: (1) marginal domains containing orthogneiss, similar in composition to the wall rock, and (2) central domains with muscovite-quartz phyllonite exhibiting a significant change in bulk rock chemistry. An important question regarding the interpretation of the shear 


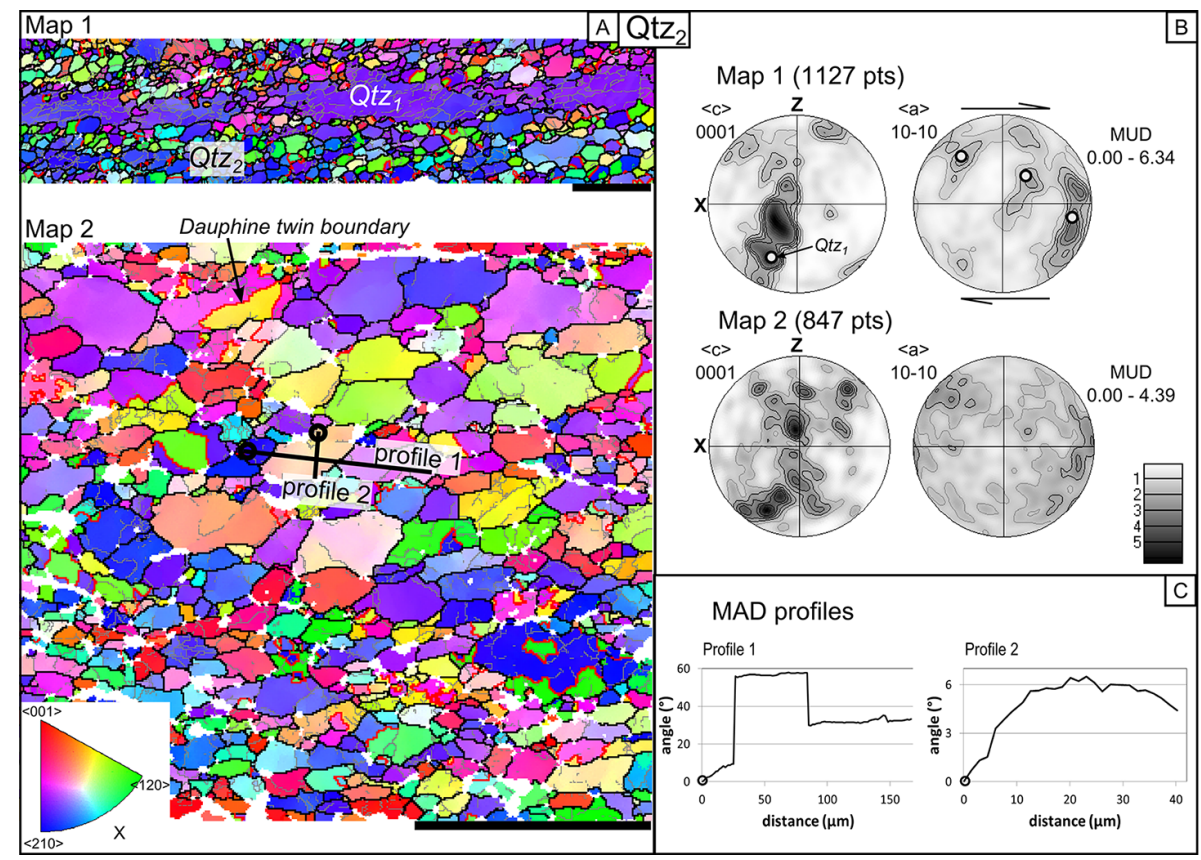

Figure 8. (a) GB (grain boundary) + IPF (inverse pole figure) map of Qtz 2 microstructures (acquisition locations marked in Figs. 5a, 6b), scale bars $200 \mu \mathrm{m}$. (b) Pole figures of the crystallographic orientation data for map 1 and map 2, plotted as one point per grain using equalarea projection and the upper hemisphere. The white dot in the pole figure for map 1 marks the orientation of the Qtz 1 grain, which occurs at the central part of the $\mathrm{Qtz}_{2}$ domain. (c) Misorientation profiles across two selected regions in map 2, where the profiles are marked by black lines and the circle represents starting position.

zone microstructures is whether both of these domains originated from the same protolith, or whether they represent preexisting heterogeneities in the wall rock, such as dykes, veins or compositional layering.

The mineralogical and chemical similarity between the orthogneissand the wall rock, as well as the gradual microstructural and mineralogical change over a broad transition zone clearly implies a wall-rock-type protolith for the orthogneiss domains. In contrast, the origin of the central phyllonites with markedly different chemical and microstructural characteristics is more ambiguous to interpret. Two scenarios can be envisaged: (i) local alteration of the wall-rock-type protolith by a metasomatic fluid or (ii) initial heterogeneity in the wall-rock-type protolith, such as a quartz-rich vein overprinted by the mylonitic deformation. Although the quartz vein scenario cannot be completely ruled out, no direct evidence was found to support it. Phyllonite A, which is still relatively similar to the wall rock composition, does not display a sharp boundary with the quartz-enriched phyllonite B (Fig. 2b). Within the wall rock, there is no evidence of premylonitic quartz veinlets. On the other hand, asymmetric reaction rims, metasomatic minerals in pressure shadows and dilational sites and syn-tectonic fracturing of porphyroclasts with associated localized but discontinuous quartz growth in extensional sites indicate the presence of a metasomatic fluid during the deformation. This, together with the consistent trends in chemical and mineralogical changes towards the shear zone centre (Fig. 10), suggests a metasomatic, rather than a vein-derived, origin for phyllonites.

\subsection{Mineral reactions and mass transfer}

The metasomatic system in Wyangala shear zones bears many similarities to the alteration patterns in other fluid-affected greenschist facies shear zones, where the feldspar breakdown to phyllosilicates and albitization of feldspars is a consistent trend (Ramberg, 1949; Kerrich et al., 1980; Pryer and Robin, 1995; Hippertt, 1998; Wintsch and Yeh, 2013). The general reaction can be summarized as follows: plagioclase $+\mathrm{K}-$ feldspar + biotite $+\mathrm{H}_{2} \mathrm{O}=$ muscovite + quartz + albite + epidote.

Further below, the particular reactions are interpreted from the specific mineral relationships observed in orthogneiss and phyllonites. The chemical formulas for the minerals as used in the reactions are given in Table 1.

\subsubsection{Orthogneiss: reactions and local mass transfer in a closed, fluid-limited system}

The mineral composition of orthogneiss differs from the wall rock by increased modes of muscovite, quartz and epidote, and decreased amounts of feldspar and biotite (Fig. 3a).

The new metasomatic muscovite $\left(\mathrm{Ms}_{2}\right)$ occurs as finegrained aggregates, aligned subparallel to the foliation fab- 


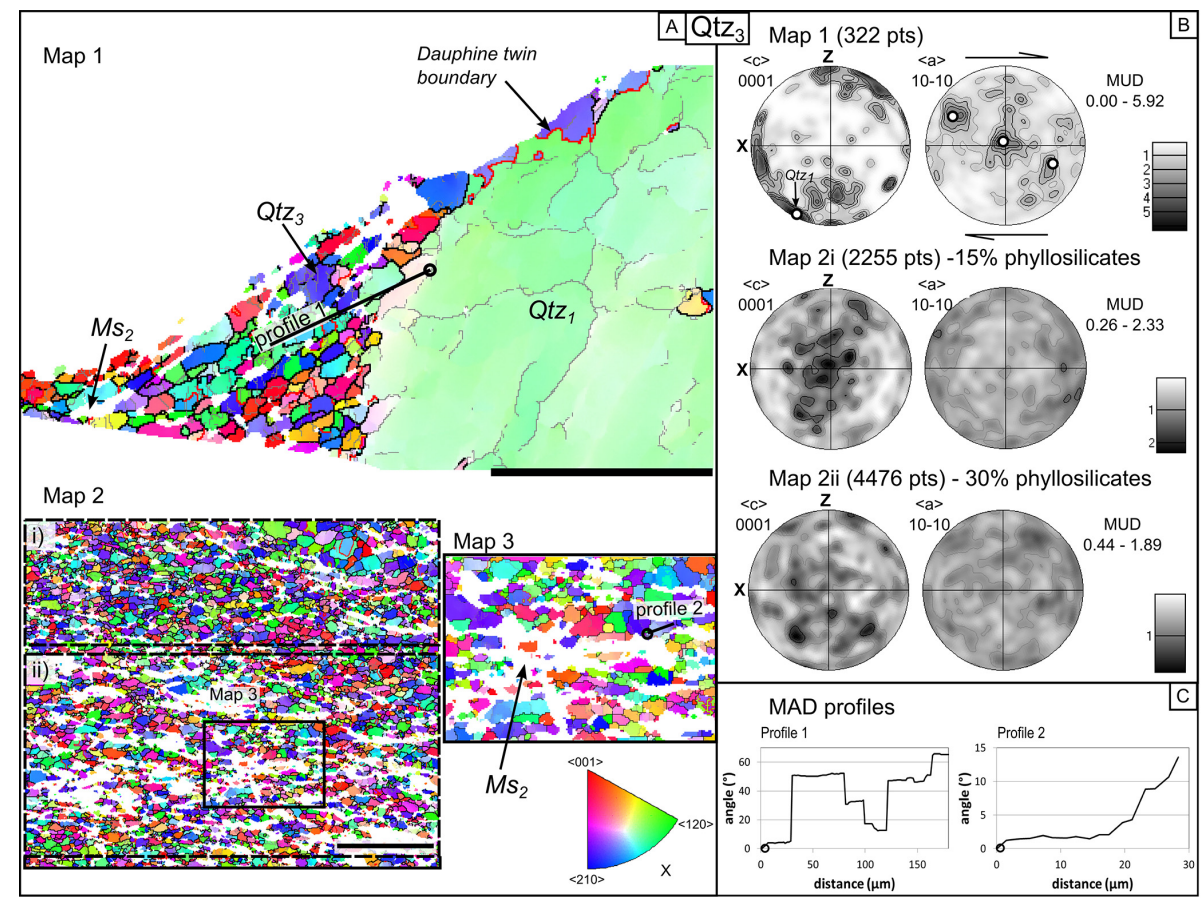

Figure 9. (a) GB (grain boundary) + IPF (inverse pole figure) map of Qtz 3 microstructures in phyllonites (acquisition locations marked in Figs. 5a, 6b). Map 2 is separated in two areas for pole figure plots. Area (i) represents quartz-rich part (15\% muscovite), while area (ii) has large muscovite mode (30\% muscovite). Map 3 is an enlarged image from map 2b, showing subgrain-scale microstructures; scale bars are $200 \mu \mathrm{m}$ long. (b) Pole figures of the crystallographic orientation data for map 2(i) and map 2(ii), plotted as one point per grain using equal-area projection and the upper hemisphere. The white dot in the pole figure for map 1 marks the orientation of the Qtz 1 grain, which occurs at the central part of Qtz 2 domain. (c) Misorientation profiles across two selected regions in map 1 and map 3, where the profiles are marked by black lines and the circle represents starting position.

ric. Muscovite-rich bands often surround or cross-cut the igneous feldspars $\left(\mathrm{Pl}_{1}\right.$ and $\left.\mathrm{Kfs}_{1}\right)$ and biotite $\left(\mathrm{Bt}_{1}\right)$ (Fig. 5be). Plagioclase, more often than K-feldspar, is surrounded by fine-grained muscovite-epidote mantles. Reactions responsible for these fabrics can be written as

$$
3 \mathrm{Kfs}_{1}+2 \mathrm{H}_{2} \mathrm{O} \rightarrow \mathrm{Ms}_{2}+6 \mathrm{Qtz}_{3}+2 \mathrm{~K}^{+}+2 \mathrm{OH}^{-}
$$

and

$$
\begin{aligned}
& 4 \mathrm{Pl}_{1}+0.8 \mathrm{H}_{2} \mathrm{O}+0.6 \mathrm{~K}^{+}+0.2 \mathrm{Fe}^{+}+2.6 \mathrm{Qtz}_{3} \rightarrow 3.2 \mathrm{Pl}_{2} \\
& +0.6 \mathrm{Ms}_{2}+0.4 \mathrm{Ep}_{2},
\end{aligned}
$$

where small amounts of pore fluid, probably provided by deformation-facilitated breakdown of igneous biotite $\left(\mathrm{Bt}_{1}\right)$ and muscovite $\left(\mathrm{Ms}_{1}\right)$ interact with the metastable igneous feldspars. As a result $\mathrm{Kfs}_{1}$ (Reaction R1) breaks down to form muscovite $\left(\mathrm{Ms}_{2}\right)$, releasing silica and $\mathrm{K}^{+}$in the solution, both of which together with small amounts of $\mathrm{Fe}^{+}$, derived from the biotite breakdown, can be further incorporated in Reaction (R2), where igneous plagioclase of andesitic composition $\left(\mathrm{Pl}_{1}\right)$ breaks down to form albitic feldspar $\left(\mathrm{Pl}_{2}\right)$, muscovite $\left(\mathrm{Ms}_{2}\right)$ and epidote $\left(\mathrm{Ep}_{2}\right)$. Pryer and Robin (1995) described a similar multi-stage reaction sequence involved in the albitization of K-feldspar to form flame perthite.
Table 1. Abbreviations and chemical formulaes for the minerals as used in the reaction equations.

\begin{tabular}{lll}
\hline Abbreviation & Mineral & Formula \\
\hline $\mathrm{Ep}_{2}$ & epidote & $\mathrm{Ca}_{2} \mathrm{Fe}_{0.5} \mathrm{Al}_{2.5}\left(\mathrm{SiO}_{4}\right)_{3}(\mathrm{OH})$ \\
$\mathrm{Kfs}_{1}, \mathrm{Kfs}_{2}$ & K-feldspar & $\mathrm{KAlSi}_{3} \mathrm{O}_{8}$ \\
$\mathrm{Ms}_{2}$ & muscovite & $\mathrm{KAl}_{3} \mathrm{Si}_{3} \mathrm{O}_{10}(\mathrm{OH})_{2}$ \\
$\mathrm{Pl}_{1}$ & oligoclase & $\mathrm{Ca}_{0 .} \mathrm{Na}_{0.8} \mathrm{Al}_{1.5} \mathrm{Si}_{2.5} \mathrm{O}_{8}$ \\
$\mathrm{Pl}_{2}$ & albite & $\mathrm{NaAlSi}_{3} \mathrm{O}_{8}$ \\
$\mathrm{Qtz}_{3}$ & quartz & $\mathrm{SiO}_{2}$ \\
\hline
\end{tabular}

The presence of intergranular fluids is necessary for the transport of the reaction components, as the parent minerals and reaction products often do not occur in a direct contact relationship. The growth of $\mathrm{Kfs}_{2}$ in pressure shadows and extensional sites (Fig. 5d, e) especially suggests that material transport is controlled by a pressure gradient, where the nucleation of new phases preferably occurs in low-pressure dilational sites. The lack of perthite lamellae in the metasomatic $\mathrm{Kfs}_{2}$ indicates the immiscibility of $\mathrm{K}^{+}$and $\mathrm{Na}^{+}$in the conditions of alteration. $\mathrm{Ca}$ content in $\mathrm{Pl}_{1}$ promotes the formation of epidote $\left(\mathrm{Ep}_{2}\right)$. The excess $\mathrm{Fe}^{+}$necessary for $\mathrm{Ep}_{2}$ production is possibly released from $\mathrm{Bt}_{1}$, which is also seen 

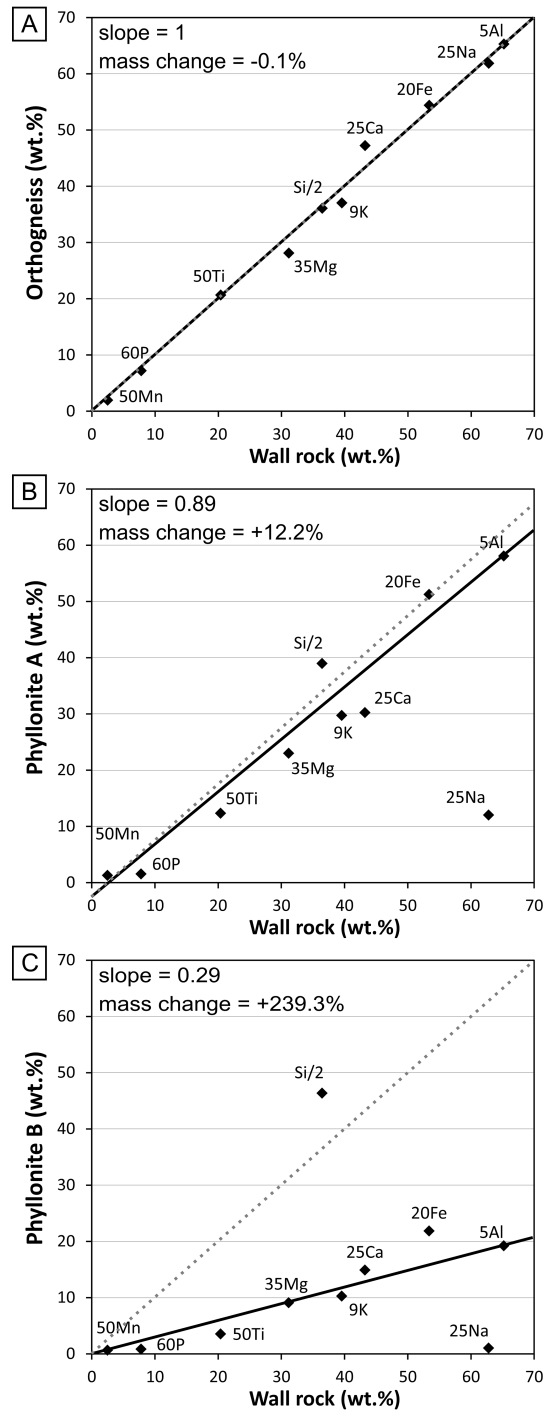

Figure 10. Isocon diagrams (Grant, 1986) showing major element concentrations for (a) orthogneiss, (b) phyllonite A and (c) phyllonite B plotted against the wall rock composition. The dashed line represents a situation of a zero mass change. The isocon (solid line) is constructed assuming immobile $\mathrm{Al}_{2} \mathrm{O}_{3}$. Elements enriched in the altered domains lie above the isocon; the elements which are depleted lie below. Scaling factors (shown in front of each element) have been applied to avoid data clustering. The detection error is smaller than the diameter of the data points (cf. Table A2).

to break down to $\mathrm{Ms}_{2}$. Quartz released in Reaction (R1) is not seen to intermix with muscovite but rather precipitate in strain shadows and fractures (Fig. 5e), suggesting high mobility of silica in the circulating fluid.

Indications of $\mathrm{Na}^{+}$mobility in fluid come from the observations of albitic rims and veinlets associated with $\mathrm{Kfs}_{1}$ and can be described by a simple exchange reaction:

$\mathrm{Kfs}_{1}+\mathrm{Na}^{+} \rightarrow \mathrm{Pl}_{2}+\mathrm{K}^{+}$, possibly governed by interface-coupled dissolutionprecipitation processes (Putnis, 2009), as a fluid phase must participate in the reaction as a transport medium for $\mathrm{Na}^{+}$and $\mathrm{K}^{+}$, as they are not always available from the surrounding phases (Fig. 5d).

In summary, the microstructures in orthogneiss suggest metastability of the wall rock assemblage during the deformation. The major reactions are feldspar-to-muscovite and biotite-to-muscovite breakdown; albitization of feldspars; and growth of metasomatic K-feldspar $\left(\mathrm{Kfs}_{2}\right)$, albite $\left(\mathrm{Pl}_{2}\right)$, epidote $\left(\mathrm{Ep}_{2}\right)$ and quartz $\left(\mathrm{Qtz}_{3}\right)$, indicating a local mobility of $\mathrm{K}^{+}, \mathrm{Na}^{+}, \mathrm{Ca}^{+}, \mathrm{Fe}^{+}$and $\mathrm{Si}^{+}$. However, the bulk rock composition of orthogneiss is highly similar to the wall rock composition (Fig. 10a) excluding the possibility of a large-scale mass transfer during alteration. A minor amount of free fluid is required to enable Reactions (R1) and (R2) to occur and to facilitate the transport of the components in all described reactions. Thus, the reactions in orthogneiss are best explained by limited fluid influx and dominance of local element "recycling" in "closed-system" conditions, where mass transfer did not exceed distances of millimetres to centimetres.

\subsubsection{Phyllonite A and B: reactions and mass transfer in an open, fluid-abundant system}

Both phyllonites display dramatic changes in mineral and chemical composition with respect to the wall rock (Fig. 10b, c). Mineralogically, the differences include almost complete loss of $\mathrm{K}$-feldspar, plagioclase and biotite, as well as increase in muscovite, quartz and epidote (Fig. 3a) content.

No igneous K-feldspar $\left(\mathrm{Kfs}_{1}\right)$ or plagioclase $\left(\mathrm{Pl}_{1}\right)$ remnants were observed in phyllonites, but the rare albite grains $\left(\mathrm{Pl}_{2}\right)$ typically associated with muscovite-quartz-epidote mantles, can either be products of the breakdown reactions of $\mathrm{Pl}_{1}$ - with $\mathrm{Pl}_{2}, \mathrm{Ms}_{2}, \mathrm{Ep}_{2}$ and $\mathrm{Qtz}_{3}$ as reaction products (Reaction R2) - or a result of an arrested/incomplete breakdown of $\mathrm{Pl}_{2}$ :

$3 \mathrm{Pl}_{2}+2 \mathrm{H}^{+}+\mathrm{K}^{+} \rightarrow \mathrm{Ms}_{2}+6 \mathrm{Qtz}_{3}+3 \mathrm{Na}^{+}$,

resulting in the production of muscovite $\left(\mathrm{Ms}_{2}\right)$ and quartz $\left(\mathrm{Qtz}_{3}\right)$ and the release of $\mathrm{Na}^{+}$in the pore fluid.

Although in some cases Reaction (R2) may be operating, Reaction (R4) is necessary to explain the eventual disappearance of albite and the general trend of $\mathrm{Na}^{+}$depletion indicated by the XRF data (Fig. 10b, c).

Both domains in the central part of the shear zone indicate net mass gains, mainly due to the increased $\mathrm{Si}^{+}$concentration. The modal analysis also shows the increase in the quartz content in both domains, suggesting external influx of $\mathrm{Si}^{+}$ fluids. No loss of $\mathrm{Si}^{+}$is observed in the adjacent orthogneiss, excluding the possibility of a lateral transport.

In summary, the chemical reactions described in this section requires "open-system" conditions with an influx of external $\mathrm{Si}^{+}$-rich hydrous fluid, undersaturated in $\mathrm{Na}^{+}$. 


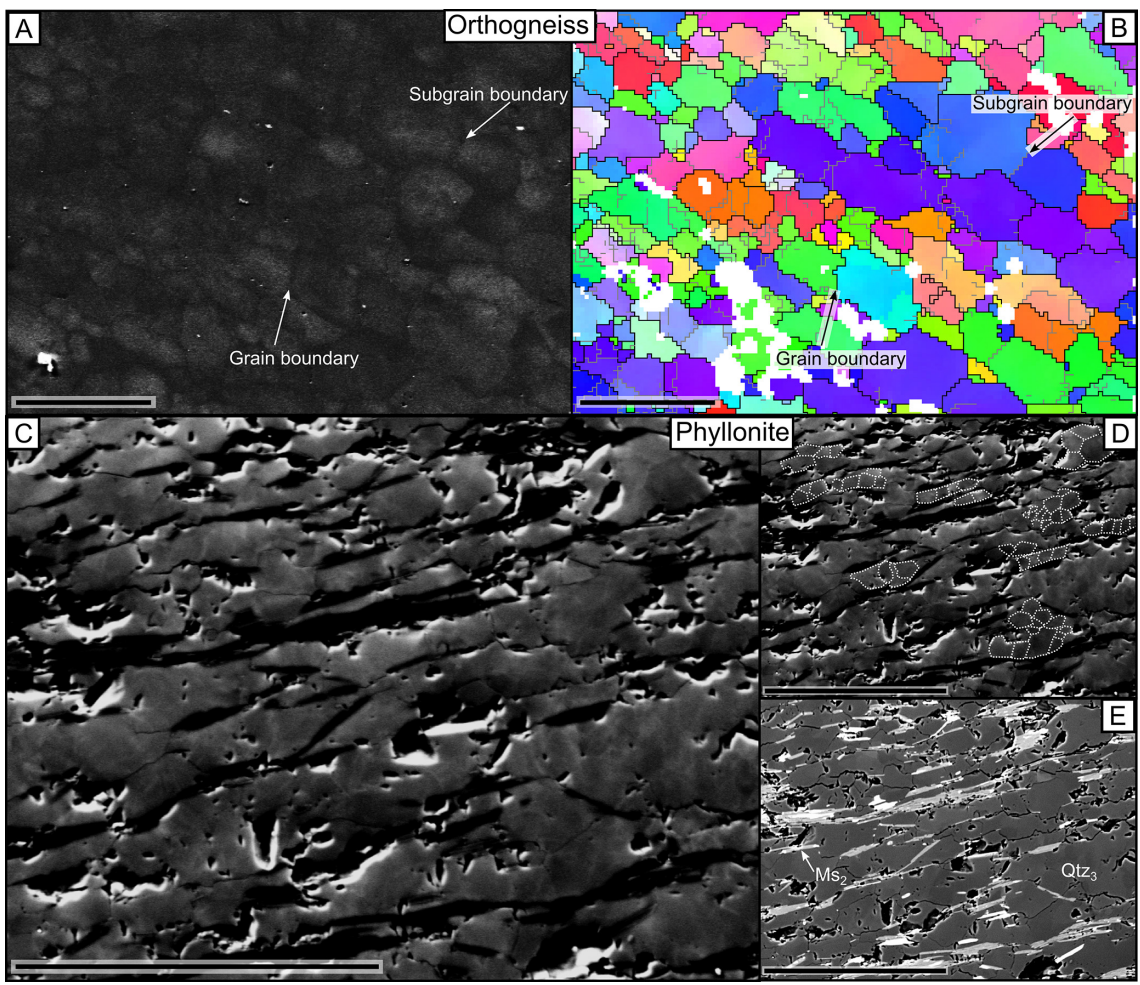

Figure 11. CL, EBSD and BSE images of quartz domains in orthogneiss and phyllonite B; scale bar is $100 \mu \mathrm{m}$. (a) CL patterns from a Qtz 2 domain showing a structure consisting of lighter polygons surrounded by darker rims; (b) EBSD image of (a) showing the grain and subgrain boundary network; (c) CL pattern from a Qtz $3-\mathrm{Ms}_{2}$ domain showing a structure dominated by thin intragranular bright lines or polygons, bordering or surrounding darker polygons; (d) area (c) with some of the polygonal structure traced; (e) BSE image of area (c) showing mineralogy and grain boundaries.

\subsection{Deformation mechanisms and strain localization}

\subsubsection{Shear zone margins: orthogneiss}

Deformation in shear zone margins occurs mainly via crystal-plastic and cataclastic processes. Ductile deformation is concentrated in quartz, while feldspar deforms in a brittle manner.

The larger $\mathrm{Qtz}_{1}$ grains, representing porphyroclastic remnants of the igneous quartz, show abundance of undulose extinction, deformation lamellae and subgrain boundaries, indicating the operation of dislocation creep processes (White, 1977; Poirier, 1980; Urai et al., 1986). The finer-grained Qtz 2 , often surrounding porphyroclasts $\left(\mathrm{Qtz}_{1}\right)$, has similar sizes and shapes to the subgrains, suggesting formation by subgrain rotation (SGR) recrystallization. The presence of serrated grain boundaries suggests a component of bulging (BLG) recrystallization involving low-temperature grain boundary migration (Hirth and Tullis, 1992), where bulging may have been partly facilitated by intergranular fluids (Mancktelow and Pennacchioni, 2004). CL patterns from orthogneiss domains also support the origin of $\mathrm{Qtz}_{2}$ by dynamic recrystallization. The newly developed grain boundaries show a distinctly different CL signature (Fig. 11), con- sistent with grain boundary generation within fluid and traceelement conditions different to that of the original igneous $\mathrm{Qtz}_{1}$. The fact that $\mathrm{Qtz}_{2}$, further interpreted as the recrystallized fraction in the orthogneiss, represents close to $70 \%$ of the orthogneiss and forms interconnected, fine-grained layers suggests relatively low rheological strength of quartz in the particular assemblage, highlighting the significance of crystal-plastic processes in the strain accommodation.

Combined EBSD data for analysed $\mathrm{Qtz}_{1}$ grains shows $c$ axes oriented synthetically oblique to the shear direction. This pattern has been previously documented to occur in mid-crustal mylonites and interpreted as a selective preservation of only those grains, which are optimally oriented for a slip on basal planes (Menegon et al., 2011).

The CPO of the recrystallized $\mathrm{Qtz}_{2}$ grains either clusters around the orientation of the adjacent porphyroclast (Fig. 8b; map 1), reflecting a "parent"-controlled misorientation relationship during a progressive subgrain rotation (Kruse et al., 2001; Stünitz et al., 2003), or, in cases when the recrystallized fraction is higher, displays a hybrid between an asymmetric single-girdle and crossed-girdle patterns (Fig. 8b; map 2), indicating slip on prism $<a>$ and rhomb < a >crystal systems (Schmid and Casey, 1986; Law et al., 1990). 
Porphyroclastic remnants of the igneous feldspar phenocrysts $\left(\mathrm{Pl}_{1}\right.$ and $\left.\mathrm{Kfs}_{1}\right)$ display clusters of angular, internally fractured and slightly displaced grains (Fig. 5a, c), indicating deformation via cataclasis. The relatively small displacement between the individual fragments suggests that fracturing itself plays a minor role in the accommodation of the finite strain. The distribution of low-solubility minerals $\left(\mathrm{Ms}_{2}\right)$ at high-stress sites between porphyroclasts and perpendicular to the shortening direction in contrast to the distribution of more soluble phases $\left(\mathrm{Pl}_{2}, \mathrm{Qtz}_{3}, \mathrm{Kfs}_{2}\right)$ in strain shadows (Fig. 5e) suggests that mass transfer occurred dominantly by pressure solution, involving a fluid phase (Rutter, 1983; Wintsch and Yi, 2002). Accordingly, elements with higher mobility - such as $\mathrm{Si}^{+}, \mathrm{Ca}^{+}, \mathrm{Na}^{+}$and $\mathrm{K}^{+}$- were transported by fluid and precipitated in the locally occurring low-pressure sites, while the elements of lower mobility, in this case $\mathrm{Al}^{+}$, were immediately incorporated in the $\mathrm{Ms}_{2}$ structure, which was the new, more stable mineral phase after the dissolution of $\mathrm{Kfs}_{1}$ and $\mathrm{Pl}_{1}$. It is important to note that the largest displacement between feldspar fragments occurs where they are surrounded by the thickest mantles of the reaction products (Fig. 5a). This observation indicates strain partitioning from feldspars to the newly created reaction products as soon as a thick-enough mantle is formed.

\subsubsection{Shear zone centre: phyllonite}

Phyllonite A and phyllonite B in the shear zone core structurally display many similarities in terms of $\mathrm{Qtz}_{1}$ and $\mathrm{Qtz}_{2}$ microstructures. Qtz 1 grains in both domains are internally deformed and shows development of subgrain boundaries, while $\mathrm{Qtz}_{2}$ grains have a strong CPO indicating rotation from porphyroclast orientation towards rhomb $<\mathrm{a}>$ and prism < a > slip systems (Fig. 8b; map 1; Schmid and Casey, 1986) with an increasing degree of recrystallization. The relatively minor fraction of the recrystallized quartz $\left(\mathrm{Qtz}_{2}\right)$ in phyllonite A suggests strong strain partitioning into the surrounding muscovite-rich matrix.

The two main differences between phyllonite A and phyllonite B domains are (1) quartz-to-muscovite ratio and (2) matrix-to-clast ratio, both of which are higher in phyllonite $\mathrm{B}$ (Figs. 3a, b; 6a, b).

All muscovite in both phyllonites is of metasomatic origin $\left(\mathrm{Ms}_{2}\right)$, formed either by a breakdown of igneous biotite or in feldspar reactions (Reactions R1, R2) and distributed by pressure solution processes, as $\mathrm{Qtz}_{3}$ tends to be associated with extensional sites in strain shadows and fractures, while muscovite is concentrated in high-stress sites around porphyroclasts, subparallel to the foliation. The consistent SPO of the muscovite grains with elongation subparallel to the shear direction thus may be controlled by syn-tectonic growth in the direction of maximum elongation.

Local variations in muscovite abundance throughout the phyllonites affect the deformation behaviour of quartz. In the fine-grained muscovite-rich layers $\left(\mathrm{Ms}_{2}=90-30 \%\right)$ quartz occurs as $\mathrm{Qtz}_{3}$-type grains and displays a lack of a clear CPO pattern (Fig. 9b; map 2). Qtz 3 CPO becomes increasingly weaker with increased amounts of muscovite (Fig. 9b; map 2i and map 2ii). The lack of CPO coupled with the small grain sizes and phase abundance is consistent with GBS as the main deformation mechanism (Kruse and Stünitz, 1999; Ree et al., 2005; Svahnberg and Piazolo, 2010). The elongated grain shapes in these domains and the abundance of intracrystalline deformation features (Fig. 9a, c) suggest that grain boundary sliding was accommodated by dislocation glide (Rybacki et al., 2010; Svahnberg and Piazolo, 2010).

A special case of $\mathrm{Qtz}_{3}$ microstructures can be seen on the tails of larger porphyroclasts (Fig. 9a; map 1) where CPO clusters around the orientation of the adjacent porphyroclasts (Fig. 9b; map 1). This is consistent with quartz precipitation from pore fluids at low-pressure sites, where the nucleation of the new grains is host-controlled. Their elongated shape subparallel to the main foliation suggests anisotropic growth of minerals commonly reported to occur during pressuresolution processes (Passchier and Trouw, 2005).

Feldspars are rare in the phyllonite and thus play a minor role in the bulk rock rheology. The prominent fracture sets filled by fine-grained muscovite suggest mechanochemical breakdown processes. The albitic composition of $\mathrm{Pl}_{2}$ is interpreted as a result of interface-coupled dissolutionprecipitation reactions (Putnis, 2009) as indicated by arrested replacement structures in the less-altered orthogneiss, where asymmetric albite rims occur around $\mathrm{Kfs}_{1}$ and $\mathrm{Pl}_{1}$. Simultaneously, albite grains may also form by neo-nucleation processes from pore fluid where a chemically different composition is obtained in response to the disequilibrium state between the deformation conditions/fluid composition and igneous feldspars. This scenario has been previously suggested by Stünitz and Fitz Gerald (1993) for similar shear zones in the Wyangala area. Both of these options indicate fluidaccompanied mass transfer processes in the shear zone.

\subsection{Deformation conditions}

The deformation conditions within the studied shear zone are estimated from (1) syn-tectonic mineral assemblages, (2) recrystallization microstructures in quartz and (3) CPO patterns in the dynamically recrystallized quartz domains.

The observed reactions (Sect. 5.2) - such as the breakdown of feldspars and biotite to muscovite, albitization of $\mathrm{K}$-feldspar and plagioclase, and formation of epidote - commonly occur in many middle crustal shear zones, deformed at greenschist facies conditions (Hippertt, 1998; e.g. Kerrich et al., 1980; Park et al., 2006). In combination with the brittleductile rheology expected at middle crustal depths, this gives the first indication of the deformation conditions.

More accurate temperature ranges can be obtained by analysing deformation microstructures in quartz. Microstructural features - such as undulose extinction, subgrain development, bulged grain boundaries and CPO patterns in 
the quartz-rich domains - indicate the operation of crystalplastic processes (Hirth and Tullis, 1992; Stipp et al., 2002). Crystal plasticity in quartz occurs by one of the three mechanisms: bulging (BLG), subgrain rotation (SGR) or hightemperature grain boundary migration. Which one of these is the most dominant largely depends on temperature. In our samples, SGR is the dominant recrystallization regime in quartz. The lobate grain boundaries observed for the recrystallized quartz grains indicate a minor component of grain boundary migration typical of the BLG recrystallization regime. In nature, the transition from BLG to SGR is found to occur at temperatures between 350 and $400{ }^{\circ} \mathrm{C}$ (Stipp et al., 2002). However, bulging-type microstructures in quartz have been reported to form as a result of postdeformational activity of grain boundary fluids (Mancktelow and Pennacchioni, 2004). This imposes some uncertainty on the lower temperature constraint.

Quartz CPO pattern therefore is a better indicator for deformation temperatures, as it does not strongly depend on the absence or presence of fluid (Mancktelow and Pennacchioni, 2004). Our samples show CPO patterns characterized by a combination of basal and prism slip (Fig. 8b; corresponding to temperatures between 300 and $400^{\circ} \mathrm{C}$; Schmid and Casey, 1986). Other authors interpret similar patterns as being indicative of deformation at temperatures close to $400{ }^{\circ} \mathrm{C}$ (Stipp et al., 2002; Lee et al., 2012). The latter temperature range is supported by the observations of frequent Dauphine twins, which in quartz form in temperatures between 300 and $400^{\circ} \mathrm{C}$ (Wenk et al., 2007; Menegon et al., 2011).

There are no direct indicators for the confining pressure; however, an approximate estimate based on the obtained temperature range $\left(300\right.$ to $\left.400^{\circ} \mathrm{C}\right)$, can be drawn using an assumption of a normal geothermal gradient $\left(30^{\circ} \mathrm{km}^{-1}\right)$. Assuming the average density of continental crust $\left(2.8 \mathrm{~g} \mathrm{~cm}^{-3}\right)$, depths of 11 and $13 \mathrm{~km}$ and pressures between 3.02 and $3.57 \mathrm{kbar}$ can be obtained.

\subsection{Model for shear zone development}

In this section we discuss a conceptual model for the development of the studied brittle-ductile shear zone. It is important to note that, although feldspar-to-muscovite reactions in the shear zone centre indicate softening and thus shear zone narrowing, the strain gradient in the studied shear zone does not represent a progressive fabric evolution with time as would be expected for an ideal Type II shear zone (Means, 1995). As we further discuss, the shear zone margins and shear zone centre experienced vastly different geological and fluid history due to a brittle precursor. A hypothetical example of such a case has been theoretically investigated by Means (1995), demonstrating how the deformation can proceed by different scenarios inside and outside the initial zone of cataclasis even when the late fabrics across the strain gradient show an apparently progressive evolution.
Here we propose a three-stage temporal development of the studied shear zone, distinguishing between two cases, representing different domains, namely case I - the shear zone margins - and case 2: the central domains (Fig. 11).

\subsubsection{Stage 1: localized cataclasis}

We suggest that the first stage of the deformation was marked by high effective stresses and fluid pressures leading to brittle failure and formation of a cataclastic fracture zone in the granitic protolith (Fig. 12a). This interpretation is based on the observation of the abundance of the large, only weakly deformed quartz porphyroclasts, in phyllonite A (Fig. 6a). If shear localization had initiated through crystal plasticity, then quartz would be highly recrystallized as seen in the orthogneiss (Fig. 5a). The preservation of the $\mathrm{Qtz}_{1}$ grains can only be possible if the weak matrix of reaction products in the central parts of the shear zone is created early in the deformation history and partitions most of the strain before any significant recrystallization of quartz takes place.

\subsubsection{Stage 2: ductile deformation}

Stage 2 is marked by ductile deformation in response to the initial cataclastic stage. Brittle failure (stage 1) resulted in a localized zone of interconnected fault-fracture mesh as described by Sibson (1996). The opening in brittle fractures and dilatancy-related pressure fluctuations around the fractures facilitated and localized the infiltration of external fluids. Subsequent microstructural development and rheology in the shear zone was mainly controlled by its proximity to this initial fracture zone. The sharp boundary separating the orthogneiss and phyllonites is interpreted to represent the extent of the initial cataclastic damage zone affected by high fluid fluxes, and the largely intact crystalline wall rock with restricted pathways for fluid infiltration (Fig. 12a, b). This distinction is also reflected in differences in phase distribution (Fig. 3a), microstructures (Figs. 3b, 4, 5) and whole-rock chemistry (Fig. 10).

Case I in Fig. 12b represents deformation at fluid-limited conditions in the shear zone margins, outside the initial cataclastic zone (Fig. 12b). Syn-tectonic retrograde reactions of igneous biotite $\left(\mathrm{Bt}_{1}\right)$ and muscovite $\left(\mathrm{Ms}_{1}\right)$ provide pore fluid which migrates along fractures and grain boundaries, facilitating microcracking, pressure-solution processes and mineral reactions to weak fine-grained polycrystalline phases (Fig. 5).

The majority of igneous quartz grains behave as a weak phase, developing subgrain and new grain boundaries through a progressive distortion of the crystal lattice. Up to $70 \%$ of the igneous quartz recrystallizes into fine-grained interconnected aggregates, accommodating most of the strain by dislocation creep processes, a typical deformation behaviour for monomineralic quartz domains (Obee and White, 1985; Fliervoet and White, 1995). Simultaneously, the ig- 


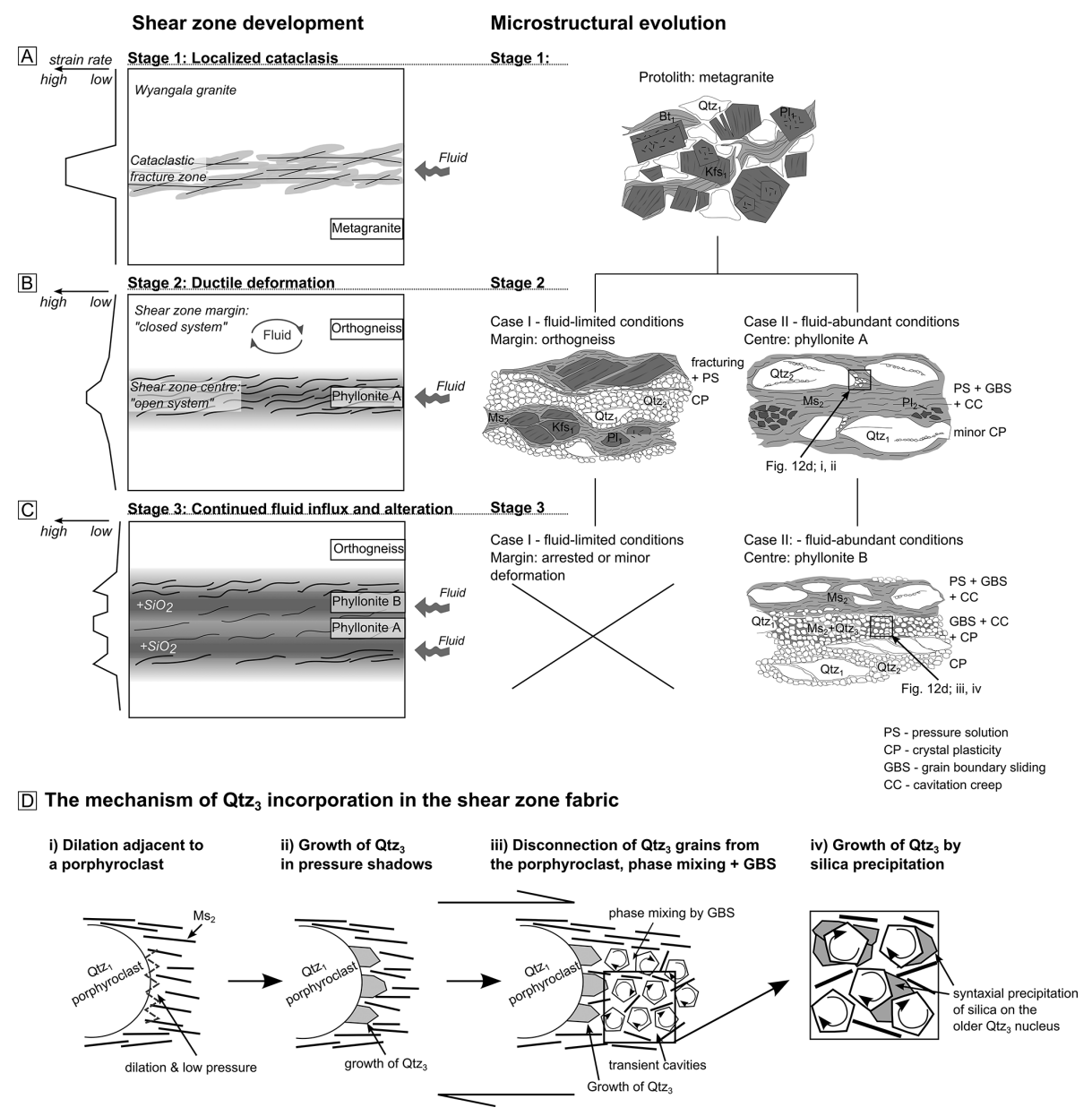

Figure 12. (a-c) Schematic illustration of the temporal (stages) and spatial (cases) fabric development of the studied shear zone; (d) the proposed mechanism for $\mathrm{Qtz}_{3}$ incorporation in the shear zone fabrics. Refer to the text for details.

neous feldspar phenocrysts undergo fragmentation by brittle failure (Fig. 5). CL patterns seen in the dynamically recrystallized Qtz 2 in the orthogneiss (Fig. 11a, b) are consistent with the presented scenario. The dark grain and subgrain boundaries indicate that recrystallization occurred at fluid conditions different to the original igneous conditions. The fact that the grain boundaries are dark is consistent with a syn-tectonic fluid containing CL signal suppressing trace elements such as Ti or $\mathrm{Al}$ (Rusk et al., 2008; Bestmann and Pennacchioni, 2015). However the limited amount of fluid available from the local reservoirs, and possibly the slow rates of its release, do not permit rapid weakening to take place. Consequently, strain localization is limited and deformation occurs throughout the rock.

Case II (Fig. 12b) represents deformation at fluid-abundant conditions in the shear zone centre. Here we assume that fabrics in phyllonite $\mathrm{A}$ is an early stage in the evolution of the central shear zone domains. This assumption is based on the fact that mineralogically and chemically phyllonite A is closer to the wall rock composition than to phyllonite B
(Fig. 10b, c). In the shear zone centre, the cataclastic protolith provides easy fluid pathways, and the dilatational lowpressure sites facilitate the infiltration of external fluids, leading to widespread and rapid mineral reactions of the metastable igneous wall rock assemblage. As a result, the load-bearing feldspar framework is rapidly destroyed and the newly produced matrix of fine-grained reaction products localizes the strain. The deformation is mainly accommodated by pressure solution processes and reaction creep in the fine-grained matrix of the reaction products. As proposed by Wintsch and Yi (2002), pressure-solution-controlled reactions can be an efficient deformation mechanism in middle crust due to the low activation energy required, leading to significant shape and volume changes even at low differential stresses (Wintsch and Yi, 2002). Consequently, the fraction of dynamically recrystallized quartz in phyllonite A is small and the remnant quartz porphyroclasts preserve sizes similar to the igneous grains in the wall rock (Fig. 6a). 


\subsubsection{Stage 3: Continued fluid influx and alteration}

Phyllonite B represents phyllonite A fabric, modified by a prolonged fluid percolation (Fig. 12c). The chemical and mineral evidence of $\mathrm{SiO}_{2}$ gains in the phyllonites (Figs. 3a, 10c) indicates that a significant amount of quartz is incorporated during the deformation. We suggest that this "new" quartz has been added in the phyllonite B microstructure through local precipitation from a pore fluid in transient dilatational sites, similar to the creep cavitation process described by Fusseis et al. (2009) and Menegon et al. (2015). The first stages of the silicification may be related to stress and strain heterogeneities in the vicinity of porphyroclasts. As seen in phyllonite A, the initial matrix, resulting from the feldspar and biotite breakdown reactions, contains little quartz. However, the mixed fine-grained $\mathrm{Qtz}_{3}-\mathrm{Ms}_{2}$ aggregates typically occur in the strain shadows of $\mathrm{Qtz}_{1}$ and feldspar porphyroclasts, where the rheologic contrast between the rigid clasts and the soft matrix is high, promoting dilation (Passchier and Trouw, 2005; Mamtani et al., 2011). Low pressures in the dilational voids attract pore fluids and enable the precipitation of material from the supersaturated fluids (Fig. 12di). Initially the growth of the new material occurs on the surface of $\mathrm{Qtz}_{1}$ porphyroclasts, as seen by the related CPO patterns of the adjacent $\mathrm{Qtz}_{3}$ grains (Fig. 9a, b; map 1; Fig. 12dii). With increasing length of these "tails" and "necks", Qtz 3 grains become disconnected from the porphyroclasts (Fig. 12diii) and, due to the fine grain sizes, transit toward the deformation by GBS, as is indicated by the random CPO patterns (Fliervoet et al., 1997) (Fig. 9a, b; map2ii). The further fluid flow (Závada et al., 2007; Rybacki et al., 2008) and silicification is then localized in these fine-grained quartz-muscovite layers by cavitation creep mechanisms. When a cavity is created next to an existing quartz grain, the nucleation of new silica will occur syntaxially due to kinetic advantages in inheriting the crystallographic orientation (Fig. 12div). Some of the subgrain boundaries observed in Qtz 3 grains (Fig. 9a; map 3) thus may reflect separate events of silica precipitation, rather than dynamic recrystallization in $\mathrm{Qtz}_{3}$. As a result the individual grains will increase in size and the interparticle spacing of the second phases $\left(\mathrm{Ms}_{2}\right)$ will also increase, leading to the development of quartz- instead of muscovite-dominated polyphase layers. CL signature of $\mathrm{Qtz}_{3}$ grains in these polyphase layers is distinctively different from the dynamically recrystallized $\mathrm{Qtz}_{2}$ in the orthogneiss (Fig. 11), often displaying intricate internal patterns consisting of lighter and darker domains and lines. As the CL signal in quartz is shown to correlate with Ti content and other trace elements (Rusk et al., 2008), we suggest that these patterns reflect continuous precipitation of silica from a slightly changing intergranular fluid.
The Qtz 3 grain coarsening may continue until the increasing grain sizes and quartz mode lead to the switch to dislocation creep mechanisms within the fine-grained material. The resulting drop in strain rates by switching from GBS deformation to dislocation creep will arrest or greatly decrease the porosity generation (i) within the fine-grained material itself and (ii) at porphyroclast-matrix boundaries, leading to the hardening of the phyllonite B domain. In this case, the resulting microstructure displays $\mathrm{CPO}$ and resembles $\mathrm{Qtz}_{2}$ layers, attributed to the origin by dynamic recrystallization. This interpretation is supported by the fact that the "reaction" quartz $\left(\mathrm{Qtz}_{3}\right)$ cannot account for all the increase in quartz mode in phyllonite B compared to the wall rock (Fig. 3b), and thus at least part of the Qtz 2 microstructure must also have an external origin.

We suggest that the shear zone may be abandoned completely once it becomes rheologically hard, leading to the activation of a new fracture in the adjacent host rock. This could happen when the rock deforms dominantly by dislocation creep and not cavitation creep due to fluid flux and cavitation-creep-related increase in quartz grain size and abundance.

\section{Conclusions}

The studied shear zone represents an example of a brittleductile deformation in the middle crust accompanied by circulating syn-deformational fluids. The fluid flow was highly localized in narrow central parts of the shear zone due to a cataclastic precursor and rapid metasomatic reactions, which created necessary porosity for fluid infiltration. As a result two structurally and chemically different domains developed across the shear zone, depending on the availability of the fluid. The "fluid-limited" shear zone margins experienced little effect of chemical processes during the deformation, preserving the granitic assemblages similar to the wall rock and deforming mainly by crystal-plastic processes in quartz. In contrast, the "wet" shear zone centre experienced extreme chemical alteration, rapid reduction in grain sizes by chemical breakdown reactions and a development of interconnected foliation partitioning the strain. The fine grain sizes further enabled fluid infiltration and creep cavitation coupled with grain boundary sliding in the highly anisotropic reaction fabric. Consequently, circulating pore fluids led to further alteration of the shear zone fabric and rheology by mineral reactions, mass transfer and incorporation of significant amounts of "external" quartz.

In summary, the existence of an initial brittle fracture system facilitated enhanced fluid flow, rapid reaction and subsequent phase mixing. This then enabled strain localization and focussed fluid flow due to creep cavitation and associated fluid pumping. 


\section{Appendix A}

Table A1. Whole-rock geochemical data. Major element concentrations and mass balance calculations of the selected samples from wall rock, orthogneiss, phyllonite A and phyllonite B. Detection error for the measurements is given in Table A1.

\begin{tabular}{|c|c|c|c|c|c|c|c|c|c|c|c|c|}
\hline \multirow[b]{2}{*}{$\begin{array}{l}\text { Sample } \\
\text { location }\end{array}$} & \multirow[b]{2}{*}{$\begin{array}{l}\text { W17 } \\
\text { wall }\end{array}$} & \multicolumn{2}{|c|}{$\begin{array}{l}\text { Measured concentrations } \\
\text { (wt } \%)\end{array}$} & \multirow{2}{*}{\multicolumn{2}{|c|}{$\begin{array}{r}\text { Scaling } \\
\text { factor }\end{array}$}} & \multicolumn{4}{|c|}{$\begin{array}{l}\text { As plotted in isocon diagrams } \\
\text { (wt \%) }\end{array}$} & \multicolumn{3}{|c|}{$\begin{array}{l}\text { Mass change rel. to } \mathrm{Al}_{2} \mathrm{O}_{3} \text { (Eq. 1) } \\
(\%)\end{array}$} \\
\hline & & $\begin{array}{r}\text { W13b } \\
\text { orthogneiss }\end{array}$ & $\begin{array}{r}\text { W21b } \\
\text { phyllonite A }\end{array}$ & & & $\begin{array}{l}\text { W17 } \\
\text { wall }\end{array}$ & $\begin{array}{r}\text { W13b } \\
\text { orthogneiss }\end{array}$ & $\begin{array}{r}\text { W21b } \\
\text { phyllonite A }\end{array}$ & $\begin{array}{r}\text { W21c } \\
\text { phyllonite B }\end{array}$ & $\begin{array}{r}\text { W13b } \\
\text { orthogneiss }\end{array}$ & $\begin{array}{c}\text { W21b } \\
\text { phyllonite A }\end{array}$ & $\begin{array}{r}\text { W21c } \\
\text { phyllonite B }\end{array}$ \\
\hline $\mathrm{Na}_{2} \mathrm{O}$ & 2.51 & 2.47 & 0.48 & 0.04 & 25 & 62.80 & 61.85 & 12.03 & 1.03 & -1.62 & -78.51 & -94.46 \\
\hline $\mathrm{MgO}$ & 0.89 & 0.80 & 0.66 & 0.26 & 35 & 31.15 & 28.11 & 23.00 & 9.10 & -9.87 & -17.14 & -0.89 \\
\hline $\mathrm{Al}_{2} \mathrm{O}_{3}$ & 13.04 & 13.05 & 11.62 & 3.84 & 5 & 65.19 & 65.26 & 58.08 & 19.22 & 0.00 & 0.00 & 0.00 \\
\hline $\mathrm{SiO} 2$ & 72.89 & 72.13 & 77.94 & 92.75 & 1 & 36.45 & 36.07 & 38.97 & 46.37 & -1.15 & 20.01 & 331.66 \\
\hline $\mathrm{P}_{2} \mathrm{O}_{5}$ & 0.13 & 0.12 & 0.03 & 0.01 & 60 & 7.80 & 7.20 & 1.56 & 0.84 & -7.79 & -77.55 & -63.46 \\
\hline $\mathrm{K}_{2} \mathrm{O}$ & 4.39 & 4.11 & 3.30 & 1.14 & 9 & 39.55 & 37.03 & 29.74 & 10.27 & -6.47 & -15.60 & -11.90 \\
\hline $\mathrm{CaO}$ & 1.73 & 1.89 & 1.21 & 0.60 & 25 & 43.23 & 47.20 & 30.23 & 14.90 & 9.08 & -21.52 & 16.95 \\
\hline $\mathrm{TiO}_{2}$ & 0.41 & 0.41 & 0.25 & 0.07 & 50 & 20.40 & 20.65 & 12.35 & 3.55 & 1.12 & -32.05 & -40.96 \\
\hline $\mathrm{Mn}_{3} \mathrm{O}_{4} *$ & 0.05 & 0.04 & 0.03 & 0.01 & 50 & 2.50 & 1.95 & 1.30 & 0.65 & -22.08 & -41.63 & -11.79 \\
\hline $\mathrm{Fe}_{2} \mathrm{O}_{3}$ & 2.67 & 2.72 & 2.56 & 1.09 & 20 & 53.38 & 54.40 & 51.24 & 21.86 & 1.80 & 7.74 & 38.94 \\
\hline Sum & 98.71 & 97.75 & 98.07 & 99.82 & & & & & & -1.08 & 11.50 & 243.06 \\
\hline LOI (calc) & 1.29 & 2.25 & 1.94 & 0.18 & & & & & & 74.40 & 68.76 & -51.76 \\
\hline LOI (meas) & 0.95 & 1.18 & 2.13 & 0.63 & & & & & & 24.08 & 151.66 & 124.99 \\
\hline Total & 99.66 & 98.93 & 100.20 & 100.45 & & & & & & -0.84 & 12.84 & 241.94 \\
\hline \multicolumn{10}{|c|}{ Total mass change (Eq. 2) } & -0.11 & 12.24 & 239.27 \\
\hline
\end{tabular}

Table A2. Absolute and relative error for the whole-rock chemical data.

\begin{tabular}{lll}
\hline $\begin{array}{l}\text { Major element } \\
(\text { wt \%) }\end{array}$ & $\begin{array}{l}\text { Absolute error } \\
(\text { wt } \%)\end{array}$ & $\begin{array}{l}\text { Relative error } \\
(\%)\end{array}$ \\
\hline 90 & \pm 0.1 to 0.2 & \pm 0.1 to 0.2 \\
50 & \pm 0.1 & \pm 0.2 \\
10 & \pm 0.05 to 0.1 & \pm 0.5 to 1 \\
1 & \pm 0.01 to 0.02 & \pm 1 to 2 \\
\hline
\end{tabular}


Acknowledgements. Financial support through the Discovery Project (DP120102060) to S. Piazolo and internal funding to L. Spruzeniece (Department of Earth and Planetary Sciences, Macquarie University) is hereby acknowledged. We thank David Adams for his help with SEM-based analyses as well as to Paul Lennox and Karol Czarnota for providing a copy of their unpublished work on Wyangala area regional geology. Special thanks to Paul Lennox for the introduction to the field. We gratefully acknowledge Florian Fusseis and Jeffrey H. Marsh for their constructive reviews, and Luca Menegon for the editorial guidance.

This is contribution 643 from the ARC Centre of Excellence for Core to Crust Fluid Systems (http://www.ccfs.mq.edu.au) and 1018 from the GEMOC Key Centre (http://www.gemoc.mq.edu.au). The analytical data were obtained using instrumentation funded by DEST Systemic Infrastructure Grants, ARC LIEF, NCRIS/AuScope, industry partners and Macquarie University.

Special Issue: "Deformation mechanisms and ductile strain localization in the lithosphere"

Edited by: L. Menegon, G. Pennacchioni, M. Stipp, N. Mancktelow, and R. Law

\section{References}

Bergman, H. and Piazolo, S.: The recognition of multiple magmatic events and pre-existing deformation zones in metamorphic rocks as illustrated by CL signatures and numerical modelling: Examples from the Ballachulish contact aureole, Scotland, Int. J. Earth Sci., 101, 1127-1148, doi:10.1007/s00531-011-0731-6, 2012.

Bestmann, M. and Pennacchioni, G.: Ti distribution in quartz across a heterogeneous shear zone within a granodiorite: The effect of deformation mechanism and strain on Ti resetting, Lithos, 227, 37-56, doi:10.1016/j.lithos.2015.03.009, 2015.

Bestmann, M. and Prior, D. J.: Intragranular dynamic recrystallization in naturally deformed calcite marble: Diffusion accommodated grain boundary sliding as a result of subgrain rotation recrystallization, J. Struct. Geol., 25, 1597-1613, doi:10.1016/S0191-8141(03)00006-3, 2003.

Billia, M. A., Timms, N. E., Toy, V. G., Hart, R. D., and Prior, D. J.: Grain boundary dissolution porosity in quartzofeldspathic ultramylonites: Implications for permeability enhancement and weakening of mid-crustal shear zones, J. Struct. Geol., 53, 2-14, doi:10.1016/j.jsg.2013.05.004, 2013.

Bos, B. and Spiers, C. J.: Frictional-viscous flow of phyllosilicatebearing fault rock: Microphysical model and implications for crustal strength profiles, J. Geophys. Res., 107, 2028, doi:10.1029/2001JB000301, 2002.

Brander, L., Svahnberg, H., and Piazolo, S.: Brittle-plastic deformation in initially dry rocks at fluid-present conditions: Transient behaviour of feldspar at mid-crustal levels, Contrib. to Mineral. Petrol., 163, 403-425, doi:10.1007/s00410-011-0677-5, 2012.

Byerlee, J.: Friction, overpressure and fault normal compression, Geophys. Res. Lett., 17, 2109, doi:10.1029/GL017i012p02109, 1990.
Czarnota, K.: The geology and structure in the Wyangala Dam Area of the Lachlan Fold Belt, NSW, University of New South Wales, 207 pp., 2002.

Demars, C., Pagel, M., Deloule, E., and Blanc, P.: Cathodoluminescence of quartz from sandstones: Interpretation of the UV range by determination of trace element distributions and fluidinclusion P-T-X properties in anthigenic quartz, Am. Mineral., 81, 891-901, 1996.

D'Lemos, R. S., Kearsley, A. T., Pembroke, J. W., Watt, G. R., and Wright, P.: Complex quartz growth histories in granite revealed by scanning cathodoluminescence techniques, Rev. Mineral., 134, 549-552, 1997.

Eilu, P., Mikucki, E. J., and Dugdale, A. L.: Alteration zoning and primary geochemical dispersion at the Bronzewing lodegold deposits, Western Australia, Miner. Depos., 36, 13-31, doi:10.1007/s001260050283, 2001.

Fliervoet, T. F. and White, S. H.: Quartz deformation in a very fine grained quartzo-feldspathic mylonite: a lack of evidence for dominant grain boundary sliding deformation, J. Struct. Geol., 17, 1095-1109, doi:10.1016/0191-8141(95)00007-Z, 1995.

Fliervoet, T. F., White, S. H., and Drury, M. R.: Evidence for dominant grain-boundary sliding deformation in greenschist- and amphibolite-grade polymineralic ultramylonites from the Redbank Deformed Zone, Central Australia, J. Struct. Geol., 19, 1495-1520, doi:10.1016/S0191-8141(97)00076-X, 1997.

Foster, D. A., Gray, D. R., Spaggiari, C., Kamenov, G., and Bierlein, F. P.: Palaeozoic Lachlan orogen, Australia; accretion and construction of continental crust in a marginal ocean setting: isotopic evidence from Cambrian metavolcanic rocks, Geol. Soc. London, Spec. Publ., 318, 329-349, doi:10.1144/SP318.12, 2009.

Fusseis, F. and Handy, M. R.: Micromechanisms of shear zone propagation at the brittle-viscous transition, J. Struct. Geol., 30, 1242-1253, doi:10.1016/j.jsg.2008.06.005, 2008.

Fusseis, F., Liu, J., Hough, R. M., and Carlo, F. De: Creep cavitation can establish a dynamic granular fluid pump in ductile shear zones, Nature, 459, 974-977, doi:10.1038/nature08051, 2009.

Glen, R. .: Thrust, extensional and strike-slip tectonics in an evolving Palaeozoic orogen - a structural synthesis of the Lachlan Orogen of southeastern Australia, Tectonophysics, 214, 341380, doi:10.1016/0040-1951(92)90205-K, 1992.

Goncalves, P., Oliot, E., Marquer, D., and Connolly, J. A. D.: Role of chemical processes on shear zone formation: An example from the grimsel metagranodiorite (Aar massif, Central Alps), J. Metamorph. Geol., 30, 703-722, doi:10.1111/j.15251314.2012.00991.x, 2012.

Grant, J. A.: The isocon diagram-a simple solution to Gresens' equation for metasomatic alteration., Econ. Geol., 81, 19761982, doi:10.2113/gsecongeo.81.8.1976, 1986.

Gray, D. R.: Tectonics of the southeastern Australian Lachlan Fold Belt: structural and thermal aspects, Geol. Soc. London, Spec. Publ., 121, 149-177, doi:10.1144/GSL.SP.1997.121.01.07, 1997.

Gresens, R. L.: Composition-volume relationships of metasomatism, Chem. Geol., 2, 47-65, doi:10.1016/0009-2541(67)900046, 1967.

Handy, M., Hirth, G., and Burgmann, R.: Continental fault structure and rheology from the frictional-to-viscous transition downward, in Continental Fault Structure and Rheology from the Frictional- 
to-Viscous Transition Downward, MIT press, Cambridge, 139181, 2007.

Hippertt, J. F.: Breakdown of feldspar, volume gain and lateral mass transfer during mylonitization of granitoid in a low metamorphic grade shear zone, J. Struct. Geol., 20, 175-193, doi:10.1016/S0191-8141(97)00083-7, 1998.

Hirth, G. and Tullis, J.: Dislocation creep regimes in quartz aggregates, J. Struct. Geol., 14, 145-159, doi:10.1016/01918141(92)90053-Y, 1992.

Karato, S.-I., Paterson, M. S., and FitzGerald, J. D.: Rheology of synthetic olivine aggregates: Influence of grain size and water, J. Geophys. Res., 91, 8151, doi:10.1029/JB091iB08p08151, 1986.

Kerrich, R., Allison, I., Barnett, R. L., Moss, S., and Starkey, J.: Microstructural and chemical transformations accompanying deformation of granite in a shear zone at Mifiville, Switzerland; with implications for stress corrosion cracking and superplastic flow, Contrib. to Mineral. Petrol., 73, 221-242, doi:10.1007/BF00381442, 1980.

Kilian, R., Heilbronner, R., and Stünitz, H.: Quartz grain size reduction in a granitoid rock and the transition from dislocation to diffusion creep, J. Struct. Geol., 33, 1265-1284, doi:10.1016/j.jsg.2011.05.004, 2011.

Kohlstedt, D. L., Evans, B., and Mackwell, S. J.: Strength of the lithosphere: Constraints imposed by laboratory experiments, J. Geophys. Res., 100, 17587, doi:10.1029/95JB01460, 1995.

Kolb, J., Rogers, A., Meyer, F. M., and Vennemann, T. W.: Development of fluid conduits in the auriferous shear zones of the Hutti Gold Mine, India: Evidence for spatially and temporally heterogeneous fluid flow, Tectonophysics, 378, 65-84, doi:10.1016/j.tecto.2003.10.009, 2004.

Kretz, R.: Symbols for rock-forming minerals., Am. Mineral., 68, 277-279, 1983.

Kruse, R. and Stünitz, H.: Deformation mechanisms and phase distribution in mafic high-temperature mylonites from the Jotun Nappe, southern Norway, Tectonophysics, 303, 223-249, doi:10.1016/S0040-1951(98)00255-8, 1999.

Kruse, R., Stünitz, H., and Kunze, K.: Dynamic recrystallization processes in plagioclase porphyroclasts, J. Struct. Geol., 23, 1781-1802, doi:10.1016/S0191-8141(01)00030-X, 2001.

Law, R. D., Schmid, S. M., and Wheeler, J.: Simple shear deformation and quartz crystallographic fabrics: a possible natural example from the Torridon area of NW Scotland, J. Struct. Geol., 12, 29-45, doi:10.1016/0191-8141(90)90046-2, 1990.

Lee, P. E., Jessup, M. J., Shaw, C. A., Hicks, G. L., and Allen, J. L.: Strain partitioning in the mid-crust of a transpressional shear zone system: Insights from the Homestake and Slide Lake shear zones, central Colorado, J. Struct. Geol., 39, 237-252, doi:10.1016/j.jsg.2012.02.006, 2012.

Lennox, P. G., Trzebski, R., Armstrong, R., and Siebel, W.: Structural evolution and granite chronology of the central Molong Zone, Eastern Lachlan Fold Belt, Australia, Aust. J. Earth Sci., 52, 79-99, doi:10.1080/08120090500109102, 2005.

Lennox, P. G., Forster, M. A., and Williams, I. S.: Emplacement and deformation ages of the Wyangala Granite, Cowra, NSW, Aust. J. Earth Sci., 61, 607-618, doi:10.1080/08120099.2014.897648, 2014.

Mamtani, M. A., Piazolo, S., Greiling, R. O., Kontny, A., and Hrouda, F.: Process of magnetite fabric development dur- ing granite deformation, Earth Planet. Sci. Lett., 308, 77-89, doi:10.1016/j.eps1.2011.05.033, 2011.

Mancktelow, N. S.: How ductile are ductile shear zones?, Geology, 34, 345-348, doi:10.1130/G22260.1, 2006.

Mancktelow, N. S. and Pennacchioni, G.: The influence of grain boundary fluids on the microstructure of quartz-feldspar mylonites, J. Struct. Geol., 26, 47-69, doi:10.1016/S01918141(03)00081-6, 2004.

Mariani, E., Brodie, K. H., and Rutter, E. H.: Experimental deformation of muscovite shear zones at high temperatures under hydrothermal conditions and the strength of phyllosilicatebearing faults in nature, J. Struct. Geol., 28, 1569-1587, doi:10.1016/j.jsg.2006.06.009, 2006.

Marsh, J. H., Johnson, S. E., Yates, M. G., and West, D. P.: Coupling of deformation and reactions during mid-crustal shear zone development: An in situ frictional-viscous transition, J. Metamorph. Geol., 27, 531-553, doi:10.1111/j.15251314.2009.00841.x, 2009.

McCaig, A. M., Wickham, S. M., and Taylor, H. P.: Deep fluid circulation in alpine shear zones, Pyrenees, France: field and oxygen isotope studies, Contrib. to Mineral. Petrol., 106, 41-60, doi:10.1007/BF00306407, 1990.

Means, W. D.: Shear zones and rock history, Tectonophysics, 247, 157-160, doi:10.1016/0040-1951(95)98214-H, 1995.

Menegon, L. and Pennacchioni, G.: Local shear zone pattern and bulk deformation in the Gran Paradiso metagranite (NW Italian Alps), Int. J. Earth Sci., 99, 1805-1825, doi:10.1007/s00531009-0485-6, 2010.

Menegon, L., Pennacchioni, G., and Spiess, R.: Dissolutionprecipitation creep of K-feldspar in mid-crustal granite mylonites, J. Struct. Geol., 30, 565-579, doi:10.1016/j.jsg.2008.02.001, 2008.

Menegon, L., Piazolo, S., and Pennacchioni, G.: The effect of Dauphin twinning on plastic strain in quartz, Contrib. to Mineral. Petrol., 161, 635-652, doi:10.1007/s00410-010-0554-7, 2011.

Menegon, L., Fusseis, F., Stünitz, H., and Xiao, X.: Creep cavitation bands control porosity and fluid flow in lower crustal shear zones, Geology, 43, 227-230, doi:10.1130/G36307.1, 2015.

Obee, H. K. and White, S. H.: Faults and associated fault rocks of the Southern Arunta block, Alice Springs, Central Australia, J. Struct. Geol., 7, 701-712, doi:10.1016/0191-8141(85)90145-2, 1985.

Oliot, E., Goncalves, P., Schulmann, K., Marquer, D., and Lexa, O.: Mid-crustal shear zone formation in granitic rocks: Constraints from quantitative textural and crystallographic preferred orientations analyses, Tectonophysics, 612-613, 63-80, doi:10.1016/j.tecto.2013.11.032, 2014.

Park, Y., Yoo, S. H., and Ree, J. H.: Weakening of deforming granitic rocks with layer development at middle crust, J. Struct. Geol., 28, 919-928, doi:10.1016/j.jsg.2006.02.005, 2006.

Passchier, C. and Trouw, R.: Microtectonics, Springer-Verlag Berlin Heidelberg, 2nd edition, 366 pp., 2005.

Paterson, S. R. and Tobisch, O. T.: Rates of processes in magmatic arcs: implications for the timing and nature of pluton emplacement and wall rock deformation, J. Struct. Geol., 14, 291-300, doi:10.1016/0191-8141(92)90087-D, 1992.

Paterson, S. R., Tobisch, O. T., and Morand, V. J.: The influence of large ductile shear zones on the emplacement and deformation of 
the Wyangala Batholith, SE Australia, J. Struct. Geol., 12, 639650, doi:10.1016/0191-8141(90)90079-E, 1990.

Pennacchioni, G. and Mancktelow, N. S.: Nucleation and initial growth of a shear zone network within compositionally and structurally heterogeneous granitoids under amphibolite facies conditions, J. Struct. Geol., 29, 1757-1780, doi:10.1016/j.jsg.2007.06.002, 2007.

Poirier, J. P.: Shear localization and shear instability in materials in the ductile field, J. Struct. Geol., 2, 135-142, doi:10.1016/01918141(80)90043-7, 1980.

Prior, D. J., Wheeler, J., Peruzzo, L., Spiess, R., and Storey, C.: Some garnet microstructures: An illustration of the potential of orientation maps and misorientation analysis in microstructural studies, J. Struct. Geol., 24, 999-1011, doi:10.1016/S01918141(01)00087-6, 2002.

Pryer, L. L. and Robin, P. Y. F.: Retrograde metamorphic reactions in deforming granites and the origin of flame perthite, J. Metamorph. Geol., 13, 645-658, doi:10.1111/j.15251314.1995.tb00249.x, 1995.

Putnis, A.: Mineral Replacement Reactions, Rev. Mineral. Geochemistry, 70, 87-124, doi:10.2138/rmg.2009.70.3, 2009.

Ramberg, H.: The facies classification of rocks: a clue to the origin of quartzo-feldspatic massivfs and veins, J. Geol., 57, 18-54, 1949.

Ree, J. H., Kim, H. S., Han, R., and Jung, H.: Grain-size reduction of feldspars by fracturing and neocrystallization in a low-grade granitic mylonite and its rheological effect, Tectonophysics, 407, 227-237, doi:10.1016/j.tecto.2005.07.010, 2005.

Rolland, Y., Cox, S., Boullier, A. M., Pennacchioni, G., and Mancktelow, N.: Rare earth and trace element mobility in mid-crustal shear zones: Insights from the Mont Blanc Massif (Western Alps), Earth Planet. Sci. Lett., 214, 203-219, doi:10.1016/S0012-821X(03)00372-8, 2003.

Rusk, B. G., Lowers, H. A., and Reed, M. H.: Trace elements in hydrothermal quartz: Relationships to cathodoluminescent textures and insights into vein formation, Geology, 36, 547-550, doi:10.1130/G24580A.1, 2008.

Rutter, E. H.: Pressure solution in nature, theory and experiment, J. Geol. Soc. London., 140, 725-740, doi:10.1144/gsjgs.140.5.0725, 1983.

Rybacki, E., Wirth, R., and Dresen, G.: High-strain creep of feldspar rocks: Implications for cavitation and ductile failure in the lower crust, Geophys. Res. Lett., 35, 1-5, doi:10.1029/2007GL032478, 2008

Rybacki, E., Wirth, R., and Dresen, G.: Superplasticity and ductile fracture of synthetic feldspar deformed to large strain, J. Geophys. Res.-Sol. Ea., 115, 1-14, doi:10.1029/2009JB007203, 2010.

Schmid, S. M. and Casey, M.: Complete fabric analysis of some commonly observed quartz c-axis fabrics, Miner. Rock Deform. Lab. Stud., 36, 263-286, 1986.

Scholz, C. H.: Fault Mechanics, in Treatise on Geophysics, vol. 6, 441-483., 2007.

Sibson, R. H.: Fault zone model, heat flow, and the depth distribution of earthquakes in the continental crust of the United States, Bull. Seismol. Soc. Am., 72, 151-163, 1982.

Sibson, R. H.: Structural permeability of fluid-driven fault-fracture meshes, J. Struct. Geol., 18, 1031-1042, doi:10.1016/01918141(96)00032-6, 1996.
Squire, R. J. and Crawford, A. J.: Magmatic characteristics and geochronology of Ordovician igneous rocks from the Cadia-Neville region, New South Wales: implications for tectonic evolution, Aust. J. Earth Sci., 54, 293-314, doi:10.1080/08120090601147001, 2007.

Stipp, M., Stünitz, H., Heilbronner, R., and Schmid, S. M.: The eastern Tonale fault zone: A "natural laboratory" for crystal plastic deformation of quartz over a temperature range from 250 to $700{ }^{\circ}$ C, J. Struct. Geol., 24, 1861-1884, doi:10.1016/S01918141(02)00035-4, 2002.

Stünitz, H. and Fitz Gerald, J. D.: Deformation of granitoids at low metamorphic grade. II: Granular flow in albite-rich mylonites, Tectonophysics, 221, 299-324, doi:10.1016/00401951(93)90164-F, 1993.

Stünitz, H., Fitz Gerald, J., and Tullis, J.: Dislocation generation, slip systems, and dynamic recrystallization in experimentally deformed plagioclase single crystals, Tectonophysics, 372, 215233, doi:10.1016/S0040-1951(03)00241-5, 2003.

Svahnberg, H. and Piazolo, S.: The initiation of strain localisation in plagioclase-rich rocks: Insights from detailed microstructural analyses, J. Struct. Geol., 32, 1404-1416, doi:10.1016/j.jsg.2010.06.011, 2010.

Tullis, J. and Yund, R. A.: Hydrolytic weakening of experimentally deformed Westerly granite and Hale albite rock, J. Struct. Geol., 2, 439-451, doi:10.1016/0191-8141(80)90005-X, 1980.

Urai, J. L., Spiers, C. J., Zwart, H. J., and Lister, G. S.: Weakening of rock salt by water during long-term creep, Nature, 324, 554557, doi:10.1038/324554a0, 1986.

Vandenberg, A. H. and Stewart, I.: Ordovician terranes of the southeastern Lachlan Fold Belt: Stratigraphy, structure and palaeogeographic reconstruction, Tectonophysics, 214, 159-176, doi:10.1016/0040-1951(92)90195-C, 1992.

Wenk, H.-R., Bortolotti, M., Barton, N., Oliver, E., and Brown, D.: Dauphiné twinning and texture memory in polycrystalline quartz, Phys. Chem. Miner., 34, 599-607, doi:10.1007/s00269007-0174-6, 2007.

White, S.: Geological significance of recovery and recrystallization processes in quartz, Tectonophysics, 39, 143-170, 1977.

White, S. H. and Knipe, R. J.: Transformation- and reactionenhanced ductility in rocks, J. Geol. Soc. London., 135, 513-516, doi:10.1144/gsjgs.135.5.0513, 1978.

Wintsch, R. P. and Yeh, M. W.: Oscillating brittle and viscous behavior through the earthquake cycle in the Red River Shear Zone: Monitoring flips between reaction and textural softening and hardening, Tectonophysics, 587, 46-62, doi:10.1016/j.tecto.2012.09.019, 2013.

Wintsch, R. P. and Yi, K.: Dissolution and replacement creep: A significant deformation mechanism in mid-crustal rocks, J. Struct. Geol., 24, 1179-1193, doi:10.1016/S0191-8141(01)00100-6, 2002.

Závada, P., Schulmann, K., Konopásek, J., Ulrich, S., and Lexa, O.: Extreme ductility of feldspar aggregates - Melt-enhanced grain boundary sliding and creep failure: Rheological implications for felsic lower crust, J. Geophys. Res. Solid Earth, 112, B10210, doi:10.1029/2006JB004820, 2007. 